\title{
Alkyne Functionalization of a Photoactivated Ruthenium Polypyridyl Complex for Click-Enabled Serum Albumin Interaction Studies
}

Anja Busemann, Can Araman, Ingrid Flaspohler, Alessandro Pratesi, Xue-Quan Zhou, Vincent H. S. van Rixel, Maxime A. Siegler, Luigi Messori, Sander I. van Kasteren, and Sylvestre Bonnet*

Cite This: Inorg. Chem. 2020, 59, 7710-7720

Read Online

ACCESS | Lلll Metrics \& More | 回 Article Recommendations Supporting Information

ABSTRACT: Studying metal-protein interactions is key for understanding the fate of metallodrugs in biological systems. When a metal complex is not emissive and too weakly bound for mass spectrometry analysis, however, it may become challenging to study such interactions. In this work a synthetic procedure was developed for the alkyne functionalization of a photolabile ruthenium polypyridyl complex, $[\mathrm{Ru}(\mathrm{tpy})(\mathrm{bpy})(\mathrm{Hmte})]\left(\mathrm{PF}_{6}\right)_{2}$, where tpy $=2,2^{\prime}: 6^{\prime}, 2^{\prime \prime}$-terpyridine, bpy $=2,2^{\prime}$-bipyridine, and Hmte $=2$-(methylthio)ethanol. In the function-

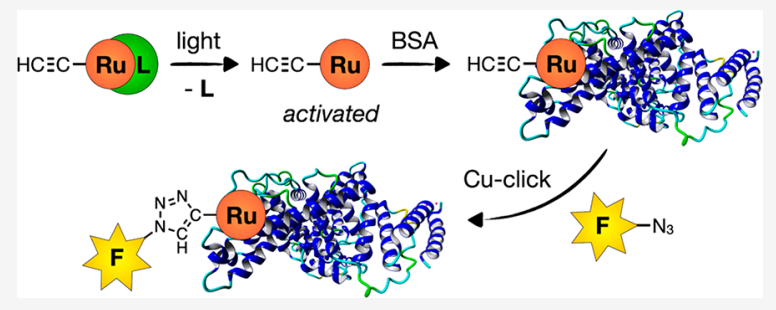
alized complex $[\mathrm{Ru}(\mathrm{HCC}$-tpy $)(\mathrm{bpy})(\mathrm{Hmte})]\left(\mathrm{PF}_{6}\right)_{2}$, where HCC-tpy $=$ $4^{\prime}$-ethynyl-2,2':6', $2^{\prime \prime}$-terpyridine, the alkyne group can be used for bioorthogonal ligation to an azide-labeled fluorophore using copper-catalyzed "click" chemistry. We developed a gel-based click chemistry method to study the interaction between this ruthenium complex and bovine serum albumin (BSA). Our results demonstrate that visualization of the interaction between the metal complex and the protein is possible, even when this interaction is too weak to be studied by conventional means such as UVvis spectroscopy or ESI mass spectrometry. In addition, the weak metal complex-protein interaction is controlled by visible light irradiation, i.e., the complex and the protein do not interact in the dark, but they do interact via weak van der Waals interactions after light activation of the complex, which triggers photosubstitution of the Hmte ligand.

\section{INTRODUCTION}

Cytotoxicity assays, cell uptake studies, and cell fractionation experiments are typically performed to investigate the biological effects and the intracellular fate of metal-based anticancer compounds. ${ }^{1-4}$ In addition, experiments regarding the interactions of the metallodrug with isolated biomolecules provide important insights about possible targets and binding sites. A frequently studied protein in bioinorganic chemistry is serum albumin. It is the most abundant protein in the bloodstream (35-50 g/L) and thus a highly likely binding partner for injected metallodrugs. ${ }^{5-7}$ Serum albumin is responsible for the transport of biomolecules, ${ }^{8}$ can act both as drug carrier and reservoir, ${ }^{9-13}$ and might support drug accumulation in tumor cells. ${ }^{9}$ It has, however, been demonstrated that interaction of anticancer drugs with serum albumin can cause undesired side effects ${ }^{9,14}$ and hinder the interaction with the actual targets of the drug. ${ }^{15}$ Bovine serum albumin (BSA) is a model protein for human serum albumin (HSA), ${ }^{13}$ with which it shares $76 \%$ of sequence homology, ${ }^{16}$ and it is a major component of cell-growth medium used for in vitro studies.

Common methods to investigate metallodrug-protein interactions are X-ray diffraction analysis, ${ }^{14,17,18}$ electrospray ionization mass spectrometry (ESI-MS), ${ }^{19,20}$ inductively coupled plasma optical emission spectrometry (ICP-OES) ${ }^{21}$ or mass spectrometry (ICP-MS), ${ }^{22} \mathrm{UV}$-vis spectroscopy, ${ }^{23}$ circular dichroism (CD) spectroscopy, ${ }^{24}$ tryptophan fluorescence spectroscopy, ${ }^{25-28}$ (nano)liquid chromatography, ${ }^{29,30}$ gel electrophoresis, ${ }^{31-33}$ capillary electrophoresis ${ }^{34,35}$ or NMR. $^{36-38}$ For emissive metallodrugs, the metal complex and hence its interaction with biomolecules can be imaged on gel electrophoresis or in cells by emission microscopy. ${ }^{39,40}$ For the nonemissive metallodrugs considered here, however, this approach is ineffective. In organic chemical biology a welldeveloped method to visualize interaction between proteins and nonemissive organic inhibitors is based on bioorthogonal chemistry. ${ }^{41}$ In this approach, the drug is modified with a small abiotic group ${ }^{42,43}$ and subsequently reacted with a fluorophore via for example the $\mathrm{Cu}(\mathrm{I})$-catalyzed azide-alkyne cycloaddition (CuAAC). ${ }^{44-48}$ For metal complexes, however, this method is quite challenging, as it requires the modification of the complex with an azide or alkyne click handle. For

Received: March 11, 2020

Published: May 12, 2020 
photosubstitutionally active polypyridyl ruthenium complexes in particular, the preparation of such functionalized analogues is a well-known synthetic challenge: Azide-functionalized ruthenium complexes are known to be unstable, ${ }^{49,50}$ and alkynes can act as ligands for ruthenium, ${ }^{51}$ leading to the formation of many byproducts. ${ }^{52}$ So far, silver-based synthetic routes have been developed toward alkyne-functionalized ruthenium complexes, where silver(I) salts are used to either enhance ligand exchange ${ }^{49}$ or to remove alkyne protecting groups. ${ }^{53}$ Silver ions, however, are bioactive, and metallodrugs synthesized according to silver-based synthetic procedures may contain traces of silver that would modify their biological properties. $^{54}$

In this work, we aimed at developing a silver-free synthetic route toward a ruthenium polypyridyl complex functionalized with a terminal alkyne group and to use such complexes to study metallodrug-serum albumin interactions on a gel using CuAAC. The complex to functionalize, $[\mathrm{Ru}(\mathrm{tpy})(\mathrm{bpy})-$ $($ Hmte $)]\left(\mathrm{PF}_{6}\right)_{2} \quad\left([\mathbf{1}]\left(\mathrm{PF}_{6}\right)_{2}\right.$, Figure 1), where tpy $=$

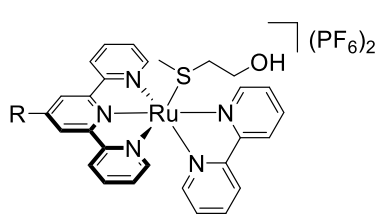

$$
\begin{array}{ll}
\mathrm{R}=\mathrm{H} & {[1]\left(\mathrm{PF}_{6}\right)_{2}} \\
\mathrm{R}=\mathrm{CCH} & {[2]\left(\mathrm{PF}_{6}\right)_{2}}
\end{array}
$$

Figure 1. Schematic representation of the ruthenium complexes $[\mathbf{1}]\left(\mathrm{PF}_{6}\right)_{2}$ and $[\mathbf{2}]\left(\mathrm{PF}_{6}\right)_{2}$.

$2,2^{\prime}: 6^{\prime}, 2^{\prime \prime}$-terpyridine, bpy $=2,2^{\prime}$-bipyridine, and Hmte $=2$ (methylthio)ethanol, is a typical example of a photosubstitutionally active ruthenium(II) complex. This complex is structurally similar to ruthenium-inhibitor conjugates recently developed for photoactivated chemotherapy (PACT). ${ }^{55}$ PACT consists of controlling the biological activity of a metal complex by selective light irradiation of the diseased tissue. $^{56-58}$ Molecularly speaking, PACT works as follows: ${ }^{59,60}$ In the dark, coordination interactions of the metal with biomolecules is prevented by the coordinated thioether (Hmte) ligand. After photosubstitution of Hmte by a solvent molecule, however, coordination of the activated drug to biological molecules becomes possible. Although for DNA this concept has been demonstrated repeatedly, ${ }^{61}$ to our knowledge controlling with light the binding of a metal complex to proteins has not yet been thoroughly investigated. Critically, substitutionally active ruthenium complexes used in PACT (e.g., $[\mathbf{1}]^{2+}$ ) are typically nonemissive because the triplet metalto-ligand charge transfer $\left({ }^{3} \mathrm{MLCT}\right)$ excited states responsible for the phosphorescence in, e.g., $[\mathrm{Ru}(\mathrm{bpy}) 3]^{2+}$ are quenched by the low-lying, dissociative triplet metal-centered excited states $\left({ }^{3} \mathrm{MC}\right)$ that precisely allow photosubstitution to occur. As a consequence, the light-controlled binding of PACT metal complexes to biomolecules can neither be followed by emission spectroscopy on gels nor by in vitro cell imaging. ${ }^{6}$ To solve this problem, a synthetic route toward $[\mathrm{Ru}(\mathrm{HCC}$ tpy $)($ bpy $)($ Hmte $)]\left(\mathrm{PF}_{6}\right)_{2}\left([2]\left(\mathrm{PF}_{6}\right)_{2}, \mathrm{HCC}\right.$-tpy $=4^{\prime}$-ethynyl$2,2^{\prime}: 6^{\prime}, 2^{\prime \prime}$-terpyridine, Figure 1), the alkyne-functionalized analogue of $[1]\left(\mathrm{PF}_{6}\right)_{2}$, was developed. The alkyne group was then used as a click handle to study the interaction between $[2]\left(\mathrm{PF}_{6}\right)_{2}$ and $\mathrm{BSA}$, in the dark and after light irradiation, by fluorophore labeling on a gel using CuAAC (Scheme 1). This method was finally compared with two known methods for studying BSA-metallodrug interaction, i.e., UV-vis spectroscopy and ESI-MS.

\section{EXPERIMENTAL SECTION}

Synthesis. $4^{\prime}$-Bromo-2,2': $6^{\prime}, 2^{\prime \prime}$-terpyridine and 2,2'-bipyridine were purchased from TCI Europe, $\mathrm{RuCl}_{3}$ was purchased from Alfa Aesar, 2-(methylthio)ethanol and tert-butyldimethylsilylethyne were purchased from Sigma-Aldrich. $[1]\left(\mathrm{PF}_{6}\right)_{2}$ was synthesized according to the literature. ${ }^{62}$ All metal complexes were synthesized in dim light and stored in darkness. All commercial reactants and solvents were used without further purification. ${ }^{1} \mathrm{H}$ NMR spectra were recorded on a Bruker AV-300 spectrometer. Chemical shifts are indicated in ppm. Mass spectra were recorded by using an MSQ Plus Spectrometer. For the proton attribution scheme, see the SI.

RCC-tpy ( $R=$ TBDMS). RCC-tpy was synthesized using an adapted literature procedure. ${ }^{52}$ To dry and degassed triethylamine (12 $\mathrm{mL}$ ) were added under a dinitrogen atmosphere $4^{\prime}$-bromo-2, $2^{\prime}: 6^{\prime}, 2^{\prime \prime}$ terpyridine ( $1.0 \mathrm{~g}, 3.2 \mathrm{mmol})$, copper(I) iodide ( $38 \mathrm{mg}, 0.20 \mathrm{mmol}$ ), dichlorobis(triphenylphosphine)palladium $(70 \mathrm{mg}, 0.10 \mathrm{mmol})$, and tert-butyldimethylsilylethyne $(1.0 \mathrm{~mL}, 5.3 \mathrm{mmol})$. The reaction mixture was stirred and refluxed for $7 \mathrm{~h}$ at $80{ }^{\circ} \mathrm{C}$ under a dinitrogen atmosphere. During reflux the same amounts of triethylamine and tert-butyldimethylsilylethyne were added twice (after $2 \mathrm{~h} 20 \mathrm{~min}$ and $4 \mathrm{~h} 40 \mathrm{~min}$ ). The solvent was evaporated with a rotary evaporator at $40{ }^{\circ} \mathrm{C}$, and the solid was dissolved in $n$-hexane and filtered. The filtrate was purified by column chromatography on silica with $n$ hexane/ethyl acetate $9: 1$ as eluent $\left(R_{f}=0.34\right)$, yielding a white solid (94\%, $1.1 \mathrm{~g}, 3.0 \mathrm{mmol}) .{ }^{1} \mathrm{H}$ NMR $(300 \mathrm{MHz}$, chloroform-d, $298 \mathrm{~K}) \delta$ 8.70 (ddd, $J=4.8,1.8,0.9 \mathrm{~Hz}, 1 \mathrm{H}, \mathrm{T} 6), 8.59(\mathrm{dt}, J=8.0,1.1 \mathrm{~Hz}, 1 \mathrm{H}$, T3), 8.49 (s, 1H, T3'), 7.85 (td, $J=7.7,1.8 \mathrm{~Hz}, 1 \mathrm{H}, \mathrm{T} 4), 7.34$ (ddd, $J$ $=7.5,4.8,1.2 \mathrm{~Hz}, 1 \mathrm{H}, \mathrm{T} 5), 1.01(\mathrm{~s}, 5 \mathrm{H}), 0.21(\mathrm{~s}, 3 \mathrm{H}) .{ }^{13} \mathrm{C}$ NMR $(75$ $\mathrm{MHz}$, chloroform-d, $298 \mathrm{~K}) \delta 155.6+155.4\left(\mathrm{~T} 2+\mathrm{T} 2^{\prime}\right), 149.1(\mathrm{~T} 6)$, 136.9 (T4), 133.3 (T4'), 124.0 (T5), 123.2 (T3'), 121.2 (T4), 103.3 (C- $\underline{\mathrm{C}}-\mathrm{Si}), 98.03$ (Ar- $\underline{\mathrm{C}}-\mathrm{C}), 26.2\left(\mathrm{Si}-\mathrm{C}-\left(\underline{\mathrm{CH}}_{3}\right)_{3}\right), 16.7\left(\mathrm{Si}-\underline{\mathrm{C}}-\left(\mathrm{CH}_{3}\right)_{3}\right)$, $-4.7\left(\mathrm{Si}-\left(\mathrm{CH}_{3}\right)_{2}\right)$. ES MS $m / z$ (calc.): $372.5\left(372.2[\mathrm{M}+\mathrm{H}]^{+}\right)$.

Scheme 1. Schematic Overview of the Interaction of an Alkyne-Functionalized Ruthenium-Based Drug with Its Biological Target after Visible Light Activation

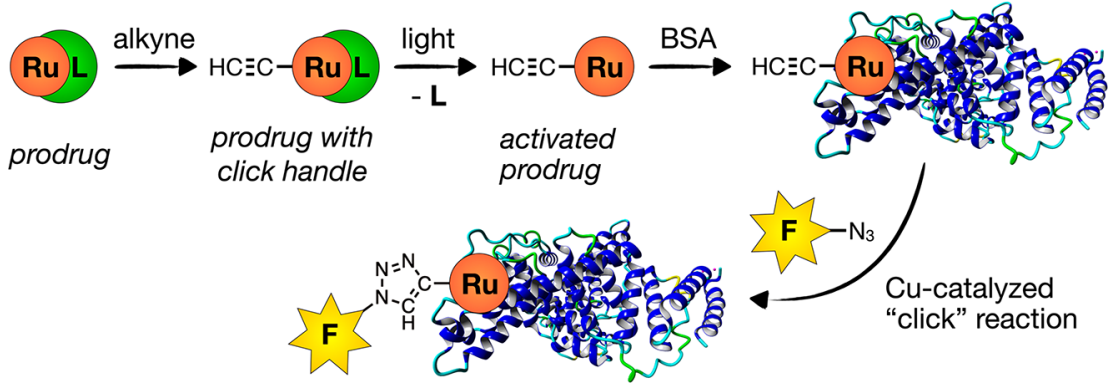


[Ru(RCC-tpy)(Cl) 3 ] (R = TBDMS), [3]. $\mathrm{RuCl}_{3} \cdot \mathrm{H}_{2} \mathrm{O}$ (500 mg, 2.41 $\mathrm{mmol})$ and RCC-tpy $(895 \mathrm{mg}, 2.41 \mathrm{mmol})$ were dissolved in ethanol $(250 \mathrm{~mL})$ and refluxed overnight while stirring. The reaction was cooled down to room temperature and chilled in the freezer overnight. The precipitate was filtered from the red solution and washed with cold ethanol and diethyl ether. Drying in vacuo yielded a brownish red solid that was used without further purification $(75 \%$, $1.05 \mathrm{~g}, 1.82 \mathrm{mmol})$.

[Ru(RCC-tpy)(bpy)(Cl)]Cl (R = TBDMS), [4]Cl. [Ru(RCCtpy) $\left.(\mathrm{Cl})_{3}\right](100 \mathrm{mg}, 0.18 \mathrm{mmol}), 2,2^{\prime}$-bipyridine $(28 \mathrm{mg}, 0.18$ $\mathrm{mmol})$, and lithium chloride $(41 \mathrm{mg}, 0.98 \mathrm{mmol})$ were dissolved in a degassed ethanol/water mixture $(20 \mathrm{~mL}, 3: 1)$. Triethylamine $(62 \mu \mathrm{L}$, $0.45 \mathrm{mmol})$ was added, and the reaction mixture was stirred at $60^{\circ} \mathrm{C}$ under dinitrogen atmosphere overnight. The reaction mixture was filtered hot over Celite, and the cake was washed with ethanol. After evaporation of the combined solvents, the crude mixture was purified by column chromatography on silica with dichloromethane/methanol $\left(9: 1, R_{f}=0.42\right)$ as eluent. Evaporation of the solvent yielded $[4] \mathrm{Cl}$ as a dark purple solid (82\%, $103 \mathrm{mg}, 0.15 \mathrm{mmol}) .{ }^{1} \mathrm{H}$ NMR $(300 \mathrm{MHz}$, methanol-d $\left.{ }_{4}, 298 \mathrm{~K}\right) \delta 10.19(\mathrm{dd}, J=5.6,1.6,0.7 \mathrm{~Hz}, 1 \mathrm{H}, \mathrm{A} 6), 8.79$ $(\mathrm{dt}, J=8.2,1.1 \mathrm{~Hz}, 1 \mathrm{H}, \mathrm{A} 3), 8.71\left(\mathrm{~s}, 2 \mathrm{H}, \mathrm{T} 3^{\prime}\right), 8.61(\mathrm{dt}, J=8.0,1.1$ $\mathrm{Hz}, 2 \mathrm{H}, \mathrm{T} 3$ ), 8.49 (dd, $J=8.1,1.2 \mathrm{~Hz}, 1 \mathrm{H}, \mathrm{B} 3), 8.34$ (td, $J=7.8,1.5$ $\mathrm{Hz}, 1 \mathrm{H}, \mathrm{A} 4), 8.02$ (ddd, $J=7.4,5.7,1.3 \mathrm{~Hz}, 1 \mathrm{H}, \mathrm{A} 5), 7.93(\mathrm{td}, J=7.9$, $1.5 \mathrm{~Hz}, 2 \mathrm{H}, \mathrm{T} 4), 7.75$ (td, $J=7.8,1.4 \mathrm{~Hz}, 1 \mathrm{H}, \mathrm{B} 4), 7.69$ (ddd, $J=5.5$, 1.6, $0.8 \mathrm{~Hz}, 2 \mathrm{H}, \mathrm{T} 6), 7.43-7.28(\mathrm{~m}, 3 \mathrm{H}, \mathrm{T} 5+\mathrm{B} 6), 7.05$ (ddd, $J=7.3$, 5.7, $1.4 \mathrm{~Hz}, 1 \mathrm{H}, \mathrm{B} 5), 1.12$ (s, 9H, Si-C- $\left.\left(\mathrm{CH}_{3}\right)_{3}\right), 0.32$ (s, 6H, Si$\left.\left(\mathrm{CH}_{3}\right)_{2}\right) \cdot{ }^{13} \mathrm{C}$ NMR $\left(75 \mathrm{MHz}\right.$, methanol-d $\left.\mathrm{d}_{4}, 298 \mathrm{~K}\right) \delta 160.1+157.5$ $(\mathrm{A} 2+\mathrm{B} 2), 159.8+159.6\left(\mathrm{~T} 2+\mathrm{T} 2{ }^{\prime}\right), 153.6(\mathrm{~A} 6), 153.2(\mathrm{~T} 6), 153.0$ (B6), 138.5 (T4), 138.3 (A4), 137.1 (B4), 129.6 (T4'), 128.8 (T5), 128.2 (A5), 127.6 (B5), 125.6 (T3'), 125.3 (T3), 124.8 (A3), 124.6 (B3), $103.7+101.8(\mathrm{Ar}-\underline{\mathrm{C}}-\mathrm{C}+\mathrm{C}-\underline{\mathrm{C}}-\mathrm{Si}), 26.6\left(\mathrm{Si}-\mathrm{C}-\left(\mathrm{CH}_{3}\right)_{3}\right), 17.6$ $\left(\mathrm{Si}-\underline{\mathrm{C}}-\left(\mathrm{CH}_{3}\right)_{3}\right),-4.6\left(\mathrm{Si}-\left(\mathrm{C}_{3}\right)_{2}\right)$. ES MS $m / z$ (calc.): 664.6 (664.1, $\left.[\mathrm{M}-\mathrm{Cl}]^{+}\right)$.

$[R u(R C C-t p y)(b p y)(H m t e)]\left(P F_{6}\right)_{2} \quad(R=T B D M S),[5]\left(P F_{6}\right)_{2}$. $[\mathrm{Ru}($ RCC-tpy) (bpy) $(\mathrm{Cl})] \mathrm{Cl}(200 \mathrm{mg}, 0.290 \mathrm{mmol})$ and 2 (methylthio)ethanol $(1.26 \mathrm{~mL}, 14.5 \mathrm{mmol})$ were dissolved in degassed water $(40 \mathrm{~mL})$ and reacted at $60{ }^{\circ} \mathrm{C}$ under a dinitrogen atmosphere overnight. After confirmation of reaction completion by TLC (silica, dichloromethane/methanol 9/1, $R_{f}=0.28$ ), a saturated aqueous potassium hexafluorophosphate solution was added. The precipitate was filtered and rinsed carefully with ice-cold water (10 $\mathrm{mL})$ and diethyl ether $(25 \mathrm{~mL})$. Drying in vacuo yielded $[5]\left(\mathrm{PF}_{6}\right)_{2}$ as an orange-brown solid $(85 \%, 250 \mathrm{mg}, 0.25 \mathrm{mmol}) .{ }^{1} \mathrm{H}$ NMR (300 $\mathrm{MHz}$, acetone- $\left.\mathrm{d}_{6}, 298 \mathrm{~K}\right) \delta 9.98(\mathrm{~d}, J=5.4 \mathrm{~Hz}, 1 \mathrm{H}, \mathrm{A} 6), 8.99(\mathrm{~s}, 2 \mathrm{H}$, T3'), 8.96 (d, $J=8.1 \mathrm{~Hz}, 1 \mathrm{H}, \mathrm{A} 3), 8.89$ (d, $J=8.1 \mathrm{~Hz}, 2 \mathrm{H}, \mathrm{T} 3), 8.72$ $(\mathrm{d}, J=8.2 \mathrm{~Hz}, 1 \mathrm{H}, \mathrm{B} 3), 8.50(\mathrm{td}, J=7.9,1.4 \mathrm{~Hz}, 1 \mathrm{H}, \mathrm{A} 4), 8.28-8.12$ (m, 3H, T4+A5), 8.09-7.98 (m, 3H, T6+B4), 7.66 (dd, $J=6.0,1.0$ $\mathrm{Hz}, 1 \mathrm{H}, \mathrm{B} 6), 7.57$ (ddd, $J=7.4,5.6,1.3 \mathrm{~Hz}, 2 \mathrm{H}, \mathrm{T5}$ ), 7.31 (ddd, $J=$ 7.3, 5.6, $1.3 \mathrm{~Hz}, 1 \mathrm{H}, \mathrm{B5}), 4.07(\mathrm{t}, J=5.1 \mathrm{~Hz}, 1 \mathrm{H}, \mathrm{OH}), 3.56(\mathrm{dt}, J=$ 5.1, 5.6 Hz, $\left.2 \mathrm{H}, \mathrm{S}-\mathrm{CH}_{2}-\mathrm{CH}_{2}\right), 2.05-1.99\left(\mathrm{~m}, 2 \mathrm{H}, \mathrm{S}-\mathrm{CH}_{2}\right), 1.56(\mathrm{~s}$, $\left.3 \mathrm{H}, \mathrm{S}-\mathrm{C}_{3}\right), 1.11\left(\mathrm{~s}, 9 \mathrm{H}, \mathrm{Si}-\mathrm{C}-\left(\mathrm{CH}_{3}\right)_{3}\right), 0.33\left(\mathrm{~s}, 6 \mathrm{H}, \mathrm{Si}-\left(\underline{\mathrm{C}}_{3}\right)_{2}\right) .{ }^{13} \mathrm{C}$ NMR $\left(75 \mathrm{MHz}\right.$, acetone-d $\left.\mathrm{d}_{6}, 298 \mathrm{~K}\right) \delta 158.7+158.6\left(\mathrm{~T} 2+\mathrm{T}^{\prime}\right)$, 157.7 + $157.6(\mathrm{~A} 2$ + B2 $), 154.4(\mathrm{~T} 6), 153.1$ (A6), $151.2(\mathrm{~B} 6), 139.9$ (T4), 139.4 (A4), 139.3 (B4), 131.7 (T4), 129.9 (T5), 129.0 (A5), 128.3 (B5), 127.1 (T3'), 126.4 (T3), 125.8 (A3), 124.9 (B3), $103.1+$ $58.93(\mathrm{Ar}-\mathrm{C}-\mathrm{C}+\mathrm{C}-\mathrm{C}-\mathrm{Si}), 59.04\left(\mathrm{~S}-\mathrm{CH}_{2}-\mathrm{CH}_{2}\right), 37.6\left(\mathrm{~S}-\mathrm{CH}_{2}\right), 26.5$ $\left(\mathrm{Si}-\mathrm{C}-\left(\mathrm{C}_{3}\right)_{3}\right), 17.3\left(\mathrm{Si}-\underline{\mathrm{C}}-\left(\mathrm{CH}_{3}\right)_{3}\right), 14.9\left({ }_{\mathrm{S}} \underline{\mathrm{CH}}_{3}\right),-4.6\left(\mathrm{Si}-\left(\underline{\mathrm{CH}}_{3}\right)_{2}\right)$. ES MS $m / z$ (calc.): $360.9\left(360.6,\left[\mathrm{M}-2 \mathrm{PF}_{6}\right]^{2+}\right)$.

$[\mathrm{Ru}(\mathrm{HCC}-\mathrm{tpy})(\mathrm{bpy})(\mathrm{Hmte})]\left(\mathrm{PF}_{6}\right)_{2}, \quad[2]\left(\mathrm{PF}_{6}\right)_{2}$. [Ru(RCC-tpy)(bpy) $(\mathrm{Hmte})]\left(\mathrm{PF}_{6}\right)_{2}(250 \mathrm{mg}, 0.247 \mathrm{mmol})$ and potassium fluoride $(72 \mathrm{mg}, 1.2 \mathrm{mmol})$ were dissolved in methanol $(6 \mathrm{~mL})$ and stirred at $30{ }^{\circ} \mathrm{C}$ overnight. The solvent was reduced in volume and a saturated aqueous potassium hexafluorophosphate solution was added until a precipitate was formed. The precipitate was filtered and rinsed carefully with ice-cold water $(10 \mathrm{~mL})$ and diethyl ether $(25 \mathrm{~mL})$. Drying in vacuo yielded $[2]\left(\mathrm{PF}_{6}\right)_{2}$ as an orange solid $(76 \%, 168 \mathrm{mg}$, $0.187 \mathrm{mmol}) .{ }^{1} \mathrm{H}$ NMR $\left(300 \mathrm{MHz}\right.$, acetone- $\left.\mathrm{d}_{6}, 298 \mathrm{~K}\right) \delta 9.97$ (ddd, $J$ $=5.6,1.6,0.8 \mathrm{~Hz}, 1 \mathrm{H}, \mathrm{A6}), 8.99\left(\mathrm{~s}, 2 \mathrm{H}, \mathrm{T} 3^{\prime}\right), 8.96(\mathrm{dt}, J=8.1,1.1 \mathrm{~Hz}$, $1 \mathrm{H}, \mathrm{A} 3), 8.88$ (ddd, $J=7.8,1.2,0.6 \mathrm{~Hz}, 2 \mathrm{H}, \mathrm{T} 3), 8.72(\mathrm{dt}, J=8.1,1.1$ $\mathrm{Hz}, 1 \mathrm{H}, \mathrm{B} 3), 8.50(\mathrm{td}, J=7.9,1.5 \mathrm{~Hz}, 1 \mathrm{H}, \mathrm{A} 4), 8.22(\mathrm{td}, J=7.9,1.5$
$\mathrm{Hz}, 2 \mathrm{H}, \mathrm{T} 4), 8.19-8.13$ (m, 1H, A5), 8.06 (ddd, $J=5.5,1.5,0.7 \mathrm{~Hz}$ $2 \mathrm{H}, \mathrm{T} 6), 8.06-7.97$ (m, 1H, B4), 7.63 (ddd, $J=5.7,1.5,0.7 \mathrm{~Hz}, 1 \mathrm{H}$, B6), 7.58 (ddd, $J=7.7,5.5,1.3 \mathrm{~Hz}, 2 \mathrm{H}, \mathrm{T} 5$ ), 7.30 (ddd, $J=7.2,5.7$, $1.3 \mathrm{~Hz}, 1 \mathrm{H}, \mathrm{B} 5), 4.55(\mathrm{~s}, 1 \mathrm{H}, \mathrm{CC} \underline{\mathrm{H}}), 4.06(\mathrm{t}, J=5.1 \mathrm{~Hz}, 1 \mathrm{H}, \mathrm{OH})$, $3.56\left(\mathrm{dt}, J=5.1,5.7 \mathrm{~Hz}, 2 \mathrm{H}, \mathrm{S}-\mathrm{CH}_{2}-\mathrm{CH}_{2}\right), 2.06-1.97(\mathrm{~m}, 2 \mathrm{H}, \mathrm{S}-$ $\left.\mathrm{CH}_{2}\right), 1.56\left(\mathrm{~s}, 3 \mathrm{H}, \mathrm{S}-\mathrm{CH}_{3}\right) .{ }^{13} \mathrm{C}$ NMR $\left(75 \mathrm{MHz}\right.$, acetone- $\left.\mathrm{d}_{6}, 298 \mathrm{~K}\right) \delta$ $158.8+158.6\left(\mathrm{~T} 2+\mathrm{T} 2^{\prime}\right), 157.7+157.6(\mathrm{~A} 2+\mathrm{B} 2), 154.5(\mathrm{~T} 6)$, 153.1 (A6), 151.2 (B6), 140.0 (T4), 139.5 (A4), 139.3 (B4), 131.3 (T4'), 129.9 (T5), 129.0 (A5), 128.3 (B5), 127.4 (T3'), 126.4 (T3), 125.8 (A3), 124.9 (B3), $87.9(\mathrm{CCH}), 81.1(\underline{\mathrm{CCH}}), 59.1\left(\mathrm{~S}^{-\mathrm{CH}_{2}-}\right.$ $\left.\mathrm{C}_{2}\right), 37.6\left(\mathrm{~S}-\mathrm{CH}_{2}\right), 15.0\left(\mathrm{~S}-\underline{\mathrm{CH}}_{3}\right)$. ES MS $m / z$ (calc.): 303.5 (303.6, $\left.\left[\mathrm{M}-2 \mathrm{PF}_{6}\right]^{2+}\right)$. High resolution ES MS $\mathrm{m} / z$ (calc.): 303.54874 $\left(303.54881,\left[\mathrm{M}-2 \mathrm{PF}_{6}\right]^{2+}\right)$. Elem. Anal. Calc. for $\mathrm{C}_{30} \mathrm{H}_{27} \mathrm{~F}_{12} \mathrm{~N}_{5} \mathrm{OP}_{2} \mathrm{RuS}$ : C, 40.19; H, 3.04; N, 7.81. Found: C, 40.21; $\mathrm{H}, 3.06$; N, 7.79.

Single Crystal X-ray Crystallography. Single crystals of $[2]\left(\mathrm{PF}_{6}\right)_{2}$ were obtained by recrystallization through liquid-vapor diffusion using acetonitrile as solvent and diisopropyl ether as countersolvent. In short, $1 \mathrm{mg}$ of $[2]\left(\mathrm{PF}_{6}\right)_{2}$ was dissolved in $1 \mathrm{~mL}$ of acetonitrile and placed in a small vial. This vial was placed in a larger vial containing $2.8 \mathrm{~mL}$ of diisopropyl ether. The large vial was closed, and vapor diffusion occurred within a few days to afford X-ray quality dark red rhombic crystals.

All reflection intensities were measured at $110(2) \mathrm{K}$ using a SuperNova diffractometer (equipped with Atlas detector) with $\mathrm{Cu} \mathrm{K \alpha}$ radiation $(\lambda=1.54178 \AA$ ) under the program CrysAlisPro (Version CrysAlisPro 1.171.39.29c, Rigaku OD, 2017). The same program was used to refine the cell dimensions and for data reduction. The structure was solved with the program SHELXS-2014/7 (Sheldrick, 2015) and was refined on $F^{2}$ with SHELXL-2014/7 (Sheldrick, 2015). Analytical numeric absorption correction using a multifaceted crystal model was applied using CrysAlisPro. The temperature of the data collection was controlled using the system Cryojet (manufactured by Oxford Instruments). The $\mathrm{H}$ atoms were placed at calculated positions using the instructions AFIX 23, AFIX 43, AFIX 137, AFIX 147, or AFIX 163 with isotropic displacement parameters having values 1.2 or $1.5 \mathrm{Ueq}$ of the attached $\mathrm{C}$ or $\mathrm{O}$ atoms. The structure of $[2]\left(\mathrm{PF}_{6}\right)_{2}$ is ordered.

Crystal structure data for $[2]\left(\mathrm{PF}_{6}\right)_{2}: 0.15 \times 0.13 \times 0.02 \mathrm{~mm}^{3}$, triclinic, $P-1, a=9.9395$ (3), $b=11.2670$ (3), $c=16.2664$ (4) $\AA, \alpha=$ $96.662(2), \beta=91.650(2), \gamma=111.580(2)^{\circ}, V=1677.48(8) \AA^{3}, Z=$ $2, \mu=6.21 \mathrm{~mm}^{-1}$, transmission factor range: $0.485-0.882$. 21777 reflections were measured up to a resolution of $(\sin \theta / \lambda) \max =0.616$ $\AA^{-1} .6568$ reflections were unique $\left(R_{\text {int }}=0.027\right)$, of which 6083 were observed $[I>2 \sigma(I)] .471$ parameters were refined. R1/wR2 $[I>$ $2 \sigma(I)]: 0.0273 / 0.0674$. R1/wR2 [all refl.]: 0.0305/0.0699. $S=1.026$. Residual electron density found between -0.49 and 0.90 e $\AA^{-3}$.

Photochemistry. Photoreactions monitored with UV-vis were performed using a Cary 50 Varian spectrometer equipped with temperature control and a magnetic stirrer. The measurements were performed in a quartz cuvette, containing $3 \mathrm{~mL}$ of solution. Irradiations were carried out under air atmosphere. Irradiation was performed from the top of the cuvette perpendicularly to the optical axis of the spectrometer using a custom-build LED irradiation setup, consisting of a high-power LED driven by a LED driver operating at $350 \mathrm{~mA}$.

For photoactivation with green light, a LED light source $(\lambda=517$ $\left.\mathrm{nm}, \Delta \lambda_{1 / 2}=23 \mathrm{~nm}, 5.42 \mathrm{~mW}, 5.4 \times 10^{-8} \mathrm{~mol} \cdot \mathrm{s}^{-1}\right)$ was used, and absorption spectrum was measured for $70 \mathrm{~min}$ at $\mathrm{T}=37^{\circ} \mathrm{C}$. $[\mathrm{Ru}]=$ $0.130 \mathrm{mM}$ for $[1]\left(\mathrm{PF}_{6}\right)_{2}$ and $0.074 \mathrm{mM}$ for $[2]\left(\mathrm{PF}_{6}\right)_{2}$. Data was analyzed using Microsoft Excel 2010.

Photosubstitution Quantum Yield. For photosubstitution quantum yield determination for $[2]\left(\mathrm{PF}_{6}\right)_{2}(0.082 \mathrm{mM})$, a LED light source $\left(\lambda=466 \mathrm{~nm}, \Delta \lambda 1 / 2=36 \mathrm{~nm}, 15.4 \mathrm{~mW}, 1.11 \times 10^{-7}\right.$ $\left.\mathrm{mol} \cdot \mathrm{s}^{-1}\right)$ was used, and UV-vis absorption spectra were recorded every $12 \mathrm{~s}$ for $30 \mathrm{~min}$ at $T=37^{\circ} \mathrm{C}$. Data was analyzed using Microsoft Excel 2010. The rate constants of the photosubstitution reaction $\left(k_{\Phi}\right)$ were derived by fitting the time evolution of the UV-vis absorption at $491 \mathrm{~nm}$ to a monoexponential decay function using Origin Pro 9.1. As the irradiation wavelength was chosen close to the isosbestic point in 
Scheme 2. Reaction Scheme of the Stepwise Synthesis of $[2]\left(\mathrm{PF}_{6}\right)_{2}{ }^{a}$

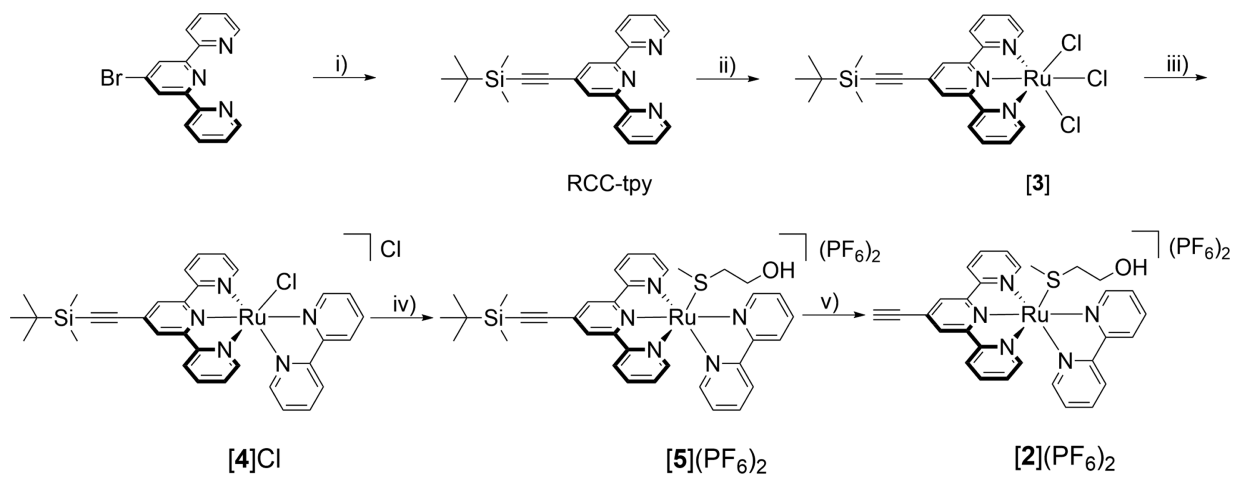

${ }^{a}$ Conditions: (i) CuI, $\mathrm{Pd}\left(\mathrm{PPh}_{3}\right)_{2} \mathrm{Cl}_{2}$, TBDMS-ethyne, $\mathrm{Et}_{3} \mathrm{~N}, 80{ }^{\circ} \mathrm{C}, \mathrm{N}_{2}, 7 \mathrm{~h} ; 95 \%$; (ii) $\mathrm{RuCl}_{3}$, ethanol, $80{ }^{\circ} \mathrm{C}, 16 \mathrm{~h}$; $75 \%$; (iii) bpy, LiCl, $\mathrm{Et}{ }_{3} \mathrm{~N}$, ethanol/water (3:1), $60{ }^{\circ} \mathrm{C}, 16 \mathrm{~h}$; 83\%; (iv) Hmte, water, $60{ }^{\circ} \mathrm{C}, \mathrm{N}_{2}, 16 \mathrm{~h}$, aq. $\mathrm{KPF}_{6}$; 85\%; (v) KF, methanol, $30{ }^{\circ} \mathrm{C}, 16 \mathrm{~h}$, aq. $\mathrm{KPF}_{6}$; $76 \%$.

the photosubstitution reactions, $A_{466}$ was assumed to be constant in time, so that the obtained rate constants could be converted into quantum yields for the photosubstitution reactions $\left(\Phi_{466}\right)$ using eq 1.

$$
\Phi_{466}=\frac{k_{\Phi} \cdot n_{\mathrm{Ru}}}{q_{\mathrm{p}} \cdot\left(1-10^{-3 * A_{466}}\right)}
$$

Here, $k_{\Phi}$ is the found photochemical rate constant, $n_{\mathrm{Ru}}$ is the total amount of ruthenium ions, $q_{\mathrm{p}}$ is the incoming photon flux, and $A_{466}$ is the absorbance at the irradiation wavelength.

Mass Spectrometry for Ru-BSA Interaction: Sample Preparation. Interactions between the photoactivable ruthenium compounds and bovine serum albumin were assessed by highresolution ESI-MS with slight modifications of the general method described in the literature. ${ }^{7,63,64}$ Two stock solutions of $[1]\left(\mathrm{PF}_{6}\right)_{2}$ and $[2]\left(\mathrm{PF}_{6}\right)_{2}$ were prepared in LC-MS grade water to a final concentration of $10^{-3} \mathrm{M}$. Another stock solution of bovine serum albumin (fatty free, from Sigma-Aldrich) was prepared in LC-MS grade water at $10^{-3} \mathrm{M}$. Appropriate aliquots of these stock solutions were mixed and diluted with water to a final protein concentration of $100 \mu \mathrm{M}$ and complex concentrations of 100,300 , or $500 \mu \mathrm{M}$. The reaction mixtures were prepared in duplicate for both ruthenium compounds; one sample was completely protected from light exposure and incubated up to $24 \mathrm{~h}$ at $37^{\circ} \mathrm{C}$. The other sample was irradiated for $1 \mathrm{~h}$ at $515 \mathrm{~nm}$ shaking at $400 \mathrm{rpm}$ and then incubated for up to $24 \mathrm{~h}$ at $37^{\circ} \mathrm{C}$.

ESI-MS. Aliquots were sampled after 2 and $24 \mathrm{~h}$ and diluted with LC-MS water at $10^{-5} \mathrm{M}$ protein final concentration with the addition of $0.1 \%$ formic acid. Respective ESI-MS spectra were acquired through direct infusion at a $10 \mu \mathrm{L} \mathrm{min}$ m $^{-1}$ flow rate in a TripleTOF 5600+ high-resolution mass spectrometer (Sciex, Framingham, MA, U.S.A.), equipped with a DuoSpray interface operating with an ESI probe. The ESI source parameters were optimized and were as follows: positive polarity, ionspray voltage floating $5400 \mathrm{~V}$, temperature $50{ }^{\circ} \mathrm{C}$, ion source gas 1 (GS1) 40; ion source gas 2 (GS2) 0; curtain gas (CUR) 15, declustering potential (DP) $250 \mathrm{~V}$, collision energy (CE) $10 \mathrm{~V}$. For acquisition, Analyst TF software 1.7.1 (Sciex) was used, and deconvoluted spectra were obtained by using the Bio Tool Kit microapplication v.2.2 embedded in PeakView software v.2.2 (Sciex).

ICP-AES. The residual fractions of the reaction mixtures prepared for the MS analysis (about $0.9 \mathrm{~mL}$ ) were used for the ICP-AES determination of the ruthenium bound to the protein, following a well-established protocol. ${ }^{65,66}$ The metalated proteins were isolated using a centrifugal filter device with a cutoff membrane of $10 \mathrm{kDa}$ and washed several times with LC-MS grade water. The final metal/ protein adducts were recovered by spinning the filters upside down at $3500 \mathrm{rpm}$ for $3 \mathrm{~min}$ with $200 \mu \mathrm{L}$ of water. The samples were mineralized in a thermoreactor at $90{ }^{\circ} \mathrm{C}$ for $8 \mathrm{~h}$ with $1.0 \mathrm{~mL}$ of $\mathrm{HCl}$ $30 \%$ Suprapur grade (Merck Millipore). After that, the samples were diluted exactly to $6.0 \mathrm{~mL}$ with Milli-Q water $(\leq 18 \mathrm{M} \Omega)$. The determination of ruthenium content in these solutions was performed using a Varian 720-ES inductively coupled plasma atomic emission spectrometer (ICP-AES). The calibration curve of ruthenium was obtained using known concentrations of a Ru ICP standard solution purchased from Sigma-Aldrich. Moreover, each sample was spiked with $1 \mathrm{ppm}$ of Ge used as an internal standard. The wavelength used for $\mathrm{Ru}$ determination was $267.876 \mathrm{~nm}$, whereas for Ge the line at $209.426 \mathrm{~nm}$ was used. The operating conditions were optimized to obtain maximum signal intensity, and between each sample, a rinse solution containing $1.0 \mathrm{~mL}$ of $\mathrm{HCl} 30 \%$ Suprapur grade and $5.0 \mathrm{~mL}$ of ultrapure water was used to avoid any "memory effect".

FIuorophore Labeling. BSA and tris ( 3 . hydroxypropyltriazolylmethyl)amine were purchased from SigmaAldrich, and Alexa Fluor 647 azide as a triethylammonium salt was purchased from Thermo Fisher (Figure S8).

Click Reaction. BSA (in 1X PBS, $15 \mu \mathrm{M}$ ) was incubated with $[2]\left(\mathrm{PF}_{6}\right)_{2}$ (in DMSO, $75 \mu \mathrm{M}$ ) at $37{ }^{\circ} \mathrm{C}$ in the dark for $24 \mathrm{~h}$ under constant shaking. After activation with green light $\left(520 \mathrm{~nm}, 76 \mathrm{~J} \cdot \mathrm{cm}^{2}\right)$ for $1 \mathrm{~h}$, the solution was incubated at $37{ }^{\circ} \mathrm{C}$ in the dark for an additional $24 \mathrm{~h}$. Samples $(50 \mu \mathrm{L})$ were taken before and after light activation (6 and $24 \mathrm{~h}$ after activation). Dark control samples as well as negative controls (without complex, without BSA, or without fluorophore) which were not activated were collected at the same time points. Samples were stored at $-20{ }^{\circ} \mathrm{C}$ if not used directly. For the click reaction, each sample was incubated with an equivalent amount of click cocktail $(50 \mu \mathrm{L})$, copper sulfate $(6.4 \mathrm{mM})$, sodium ascorbate $(37.5 \mathrm{mM})$, tris(3-hydroxypropyltriazolylmethyl)amine (THPTA) (in DMSO, $1.3 \mathrm{mM}$ ), Tris-HCl (100 mM, pH 8.0), and Alexa Fluor 647 azide (in DMSO, $5 \mu \mathrm{M}$ )) at rt under gentle shaking for $1 \mathrm{~h}$ in the dark. The click reaction was quenched with an SDS loading buffer $(50 \mu \mathrm{L})$ and used immediately for in-gel fluorescence. Alkyne-substituted vinculin, homopropargylglycine-Vin (Hpg-Vin), was used as the positive control and prepared by Dr. Can Araman according to a published procedure. ${ }^{67}$

Note that electrophoresis was performed in the dark. Two $\mu \mathrm{g}$ of protein was added to each well of a 15 well $1.5 \mathrm{~mm}$ SDS gel at $200 \mathrm{~V}$ for $1 \mathrm{~h}$. Protein concentration of each sample was measured using a Qubit reader (Thermo Fisher). Fluorescent bands of the SDS gels were visualized using a BioRad ChemiDoc Touch Imaging System with Alexa647 filter. Coomassie staining was applied overnight and destained with the destaining solution ( $\mathrm{MeOH}$ :water:AcOH; 5:4:1).

\section{RESULTS AND DISCUSSION}

Synthesis and Characterization. An alkyne-functionalized analogue of the ruthenium polypyridyl complex $[1]\left(\mathrm{PF}_{6}\right)_{2}$ was synthesized by placing the alkyne moiety in the $4^{\prime}$-position of the tpy ligand. By doing so, the symmetry of the resulting complex was preserved, while alkyne functionalization on any other positions on the ligands would lead to the formation of several stereoisomers. Since the alkyne-protecting 
triisopropylsilyl (TIPS) group was reported to be difficult to remove, ${ }^{68}$ the use of trimethylsilyl (TMS) and tertbutyldimethylsilyl (TBDMS) was investigated. Both are known protecting groups for terminal alkynes, but they are more readily removed compared to TIPS. In our hands, the TMS protecting group was not stable enough to withstand subsequent reaction steps, leading to the formation of undesired byproducts. Therefore, the synthesis of the alkynefunctionalized ruthenium complex $[2]\left(\mathrm{PF}_{6}\right)_{2}$ was finally achieved using the TBDMS group (Scheme 2). The alkynefunctionalized tpy ligand (RCC-tpy, where $\mathrm{R}=\mathrm{TBDMS}$ ) was synthesized using a Sonogashira coupling, ${ }^{52}$ purified by column chromatography, and the desired product RCC-tpy was obtained with a yield of $95 \%$. Although ruthenium(II) precursors can be used, too, ${ }^{53,69}$ TBDMS was stable enough to withstand Takeuchi's classical synthetic route ${ }^{70}$ toward $[\mathrm{Ru}(\mathrm{tpy})(\mathrm{bpy}) \mathrm{Cl}] \mathrm{Cl}$ complexes, which involves binding of the terpyridine chelate to a ruthenium(III) precursor, followed by bipyridine coordination in reducing conditions. RCC-tpy was hence reacted with ruthenium(III) chloride, to obtain $\left[\mathrm{Ru}(\mathrm{RCC}-\mathrm{tpy})(\mathrm{Cl})_{3}\right]([3])$. The reaction with bpy in ethanol/water (3:1) yielded the desired ruthenium(II) product $[\mathrm{Ru}(\mathrm{RCC}$-tpy $)(\mathrm{bpy})(\mathrm{Cl})] \mathrm{Cl}([4] \mathrm{Cl})$ in a yield of $83 \%$; in this classical reaction the reducing of $\mathrm{Ru}(\mathrm{III})$ is obtained by the combined action of triethylamine as electron donor and boiling ethanol. The chloride ligand was then substituted in a reaction with $\mathrm{Hmte}$ in pure water at $60{ }^{\circ} \mathrm{C}$ for $16 \mathrm{~h}$. Precipitation of the product after the reaction was achieved by addition of saturated aqueous potassium hexafluorophosphate. Two singlets at 1.10 and $0.32 \mathrm{ppm}$ in the ${ }^{1} \mathrm{H}$ NMR spectrum in acetone- $\mathrm{d}_{6}$ (Figure S1) integrating for nine and six protons, respectively, and the major peak in the MS spectrum at $\mathrm{m} / z=$ 360.9 confirmed the stability of the TBDMS protecting group during ligand exchange and the nature of $[\mathrm{Ru}(\mathrm{RCC}$-tpy)(bpy) $($ Hmte $)]^{2+}$ (calc. $m / z=360.6$ for $[5]^{2+}$ ). Noteworthy, when coordination of Hmte was performed at $80{ }^{\circ} \mathrm{C}$, TBDMS protection was not fully retained, resulting in the formation of byproducts. Analysis of these byproducts showed that the ruthenium center can act as a catalyst in the reaction of a terminal alkyne with alcohol groups (ethanol or Hmte), leading to the formation of enol ethers (Scheme S1). ${ }^{71}$ These findings emphasized that the TBDMS protecting group was necessary to protect the alkyne as long as the ruthenium center bears labile ligands or goes through ligand exchange. Controlled deprotection of the alkyne in $[5]\left(\mathrm{PF}_{6}\right)_{2}$ was performed using 5 equiv of potassium fluoride in methanol at $30{ }^{\circ} \mathrm{C} .{ }^{1} \mathrm{H}$ NMR in acetone- $\mathrm{d}_{6}$ shows the disappearance of the two singlets of the protecting TBDMS group concomitant with the appearance of a new singlet at $4.55 \mathrm{ppm}$ integrating for one proton, characteristic for the free alkyne (Figure S2). In combination with mass spectrometry, the successful synthesis of $[\mathrm{Ru}(\mathrm{HCC}$-tpy $)(\mathrm{bpy})(\mathrm{Hmte})]\left(\mathrm{PF}_{6}\right)_{2}\left([2]\left(\mathrm{PF}_{6}\right)_{2}, \mathrm{~m} / z=\right.$ 303.5; calc. $m / z=303.6$ for $\left.[2]^{2+}\right)$ was confirmed.

Dark red rhombic single crystals of $[2]\left(\mathrm{PF}_{6}\right)_{2}$ suitable for Xray structure determination were obtained through slow vapor diffusion of diisopropyl ether into a solution of $[2]\left(\mathrm{PF}_{6}\right)_{2}$ in acetonitrile (Figure 2). Selected bond lengths and angles are summarized in Table 1, together with those reported for the structure of $[1]\left(\mathrm{PF}_{6}\right)_{2}{ }^{62}$ The alkyne bond length $(\mathrm{C} 17 \equiv \mathrm{C} 16$ $=1.180(4) \AA)$ is comparable with that of published data. ${ }^{53}$ The $\mathrm{Ru}-\mathrm{N}$ bond distances of the tpy as well as of the bpy ligand in $[2]\left(\mathrm{PF}_{6}\right)_{2}$ are not significantly different from those in the nonfunctionalized analogue $[1]\left(\mathrm{PF}_{6}\right)_{2}$. Hmte is bound via the

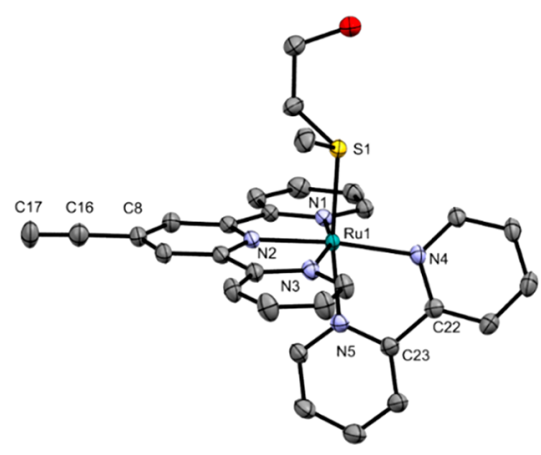

Figure 2. Displacement ellipsoid ( $50 \%$ probability level) of the cationic part of $[2]\left(\mathrm{PF}_{6}\right)_{2}$ as observed in the crystal structure at $110(2) \mathrm{K}$. Counterions and $\mathrm{H}$ atoms have been omitted for clarity.

Table 1. Selected Bond Lengths (̊̊), Angles (deg), and Torsion Angles $(\mathrm{deg})$ for $[2]\left(\mathrm{PF}_{6}\right)_{2}$ and $[1]\left(\mathrm{PF}_{6}\right)_{2}$

\begin{tabular}{ccc} 
& {$[\mathbf{2}]\left(\mathrm{F}_{6}\right)_{2}$} & {$[\mathbf{1}]\left(\mathrm{PF}_{6}\right)_{2}{ }^{a}$} \\
$\mathrm{Ru}-\mathrm{N} 1$ & $2.0566(19)$ & $2.061(1)$ \\
$\mathrm{Ru}-\mathrm{N} 2$ & $1.9568(19)$ & $1.961(1)$ \\
$\mathrm{Ru}-\mathrm{N} 3$ & $2.0709(19)$ & $2.066(1)$ \\
$\mathrm{Ru}-\mathrm{N} 4$ & $2.0948(18)$ & $2.092(1)$ \\
$\mathrm{Ru}-\mathrm{N} 5$ & $2.0676(19)$ & $2.064(1)$ \\
$\mathrm{Ru}-\mathrm{S} 1$ & $2.3764(6)$ & $2.3690(5)$ \\
$\mathrm{C} 17-\mathrm{C} 16$ & $1.180(4)$ & \\
$\mathrm{C} 16-\mathrm{C} 8$ & $1.440(3)$ & \\
$\mathrm{N} 1-\mathrm{Ru} 1-\mathrm{N} 2$ & $79.90(8)$ & $70.08(6)$ \\
$\mathrm{N} 2-\mathrm{Ru} 1-\mathrm{N} 3$ & $79.92(8)$ & $159.31(6)$ \\
$\mathrm{N} 1-\mathrm{Ru} 1-\mathrm{N} 3$ & $159.55(8)$ & $78.12(6)$ \\
$\mathrm{N} 4-\mathrm{Ru} 1-\mathrm{N} 5$ & $78.12(7)$ & \\
${ }^{a}$ Data taken from Bahreman et al. ${ }^{62}$ & \\
\hline
\end{tabular}

sulfur atom with a $\mathrm{Ru}-\mathrm{S}$ bond distance of $2.3764(6) \AA$, which is slightly longer than in $[1]\left(\mathrm{PF}_{6}\right)_{2} \cdot{ }^{72}$ Therefore, it can be concluded that the alkyne moiety has no significant effect on the geometry of $[2]\left(\mathrm{PF}_{6}\right)_{2}$ compared to $[1]\left(\mathrm{PF}_{6}\right)_{2}$.

Photochemistry of $[2]\left(\mathrm{PF}_{6}\right)_{2} \cdot[1]\left(\mathrm{PF}_{6}\right)_{2}$ is known to be stable in the dark, while light irradiation initiates the substitution of the thioether ligand by a water molecule $\left([6]^{2+}\right.$, Scheme 3). ${ }^{62}$ To test whether alkyne-functionalized

Scheme 3. Photosubstitution Reaction of $[1]\left(\mathrm{PF}_{6}\right)_{2}$ and $[2]\left(\mathrm{PF}_{6}\right)_{2}$ in Aqueous Solution

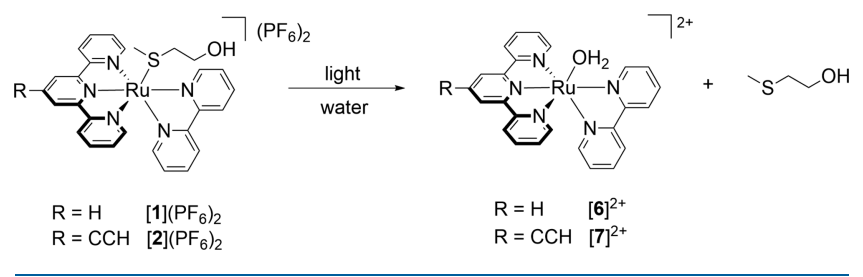

$[2]\left(\mathrm{PF}_{6}\right)_{2}$ possesses the same photochemical properties, UVvis spectra of a solution of $[2]\left(\mathrm{PF}_{6}\right)_{2}$ in water were recorded. The absorbance spectrum of $[2]\left(\mathrm{PF}_{6}\right)_{2}$ in aqueous solution is characterized by an absorption maximum at $470 \mathrm{~nm}$, and when kept in the dark, the complex is stable at $37{ }^{\circ} \mathrm{C}$ for $16 \mathrm{~h}$ (Figure S4). However, when irradiated with a green LED (517 $\mathrm{nm})$ at $37{ }^{\circ} \mathrm{C}$ in water, the $\mathrm{UV}-$ vis spectrum of $[2]\left(\mathrm{PF}_{6}\right)_{2}$ showed a bathochromic shift of the maximum to $491 \mathrm{~nm}$ (Figure 3). This change was accompanied by a change of the major peaks in MS spectra from $m / z=303.2\left([2]^{2+}\right.$, calc. $m / z$ 


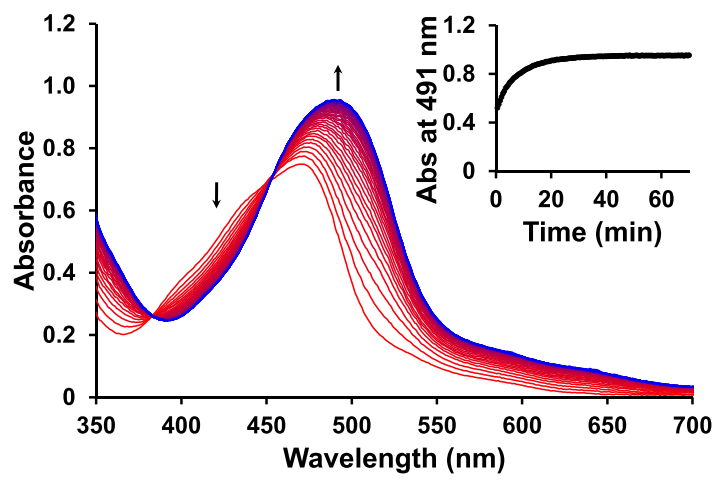

Figure 3. Evolution of the UV-vis absorption spectra (region 350$700 \mathrm{~nm})$ of a solution of $[2]\left(\mathrm{PF}_{6}\right)_{2}$ in water upon green light irradiation. Conditions: $[\mathrm{Ru}]=0.074 \mathrm{mM}, T=37^{\circ} \mathrm{C}$, light source: $\lambda$ $=517 \mathrm{~nm}, \Delta \lambda_{1 / 2}=23 \mathrm{~nm}, 5.42 \mathrm{~mW}$, photon flux $\Phi=5.4 \times 10^{-8} \mathrm{~mol}$. $\mathrm{s}^{-1}, V=3 \mathrm{~mL}$, under air atmosphere. Inset: time evolution of absorbance at wavelength $491 \mathrm{~nm}$.

= 303.6) to $m / z=266.2$, indicating the formation of the aqua complex $\left[\mathrm{Ru}\left(\mathrm{HCC} \text {-tpy) (bpy) }\left(\mathrm{OH}_{2}\right)\right]^{2+}\left([7]^{2+}\right.\right.$, calc. $m / z=$ 266.5, Figure S6). According to mass spectrometry, the photosubstitution was completed after approximately $30 \mathrm{~min}$ of irradiation, after which no traces of the starting complex could be observed, while the initial spectrum shows no traces of the photoproduct (Figure S6). The photosubstitution quantum yield in water, $\Phi_{466}$, measured by UV-vis spectroscopy by irradiation near the isosbestic point (466 nm), was found to be 0.017 at $37{ }^{\circ} \mathrm{C}($ Table 2$)$. This value is slightly lower than that found for the nonfunctionalized analogue $[\mathbf{1}]\left(\mathrm{PF}_{6}\right)_{2}$ under blue light irradiation $\left(\Phi_{452}=0.022\right) .{ }^{62} \mathrm{In}$ addition, $[1]\left(\mathrm{PF}_{6}\right)_{2}$ and $[2]\left(\mathrm{PF}_{6}\right)_{2}$ show similar low singlet oxygen generation quantum yields $\left(\Phi_{\Delta}\right)$ and, as expected, negligible phosphorescence quantum yields $\Phi_{\mathrm{P}}$ (Table 2, Figure S7). These results demonstrated that the alkyne moiety in $[2]^{2+}$, though slightly lowering the photosubstitution quantum yield, does not qualitatively alter the photochemical properties of the complex, compared to $[1]^{2+}$.

CuAAC Reaction on the Ruthenium Complex. To test whether the alkyne-functionalization allows for the CuAAC reaction on the ruthenium complex, $[2]\left(\mathrm{PF}_{6}\right)_{2}$ was reacted with an excess of 2-(2-(2-azidoethoxy)ethoxy)ethanol in the presence of catalytic amounts of $\mathrm{Cu}$ (II) and sodium ascorbate in a water/acetone mixture $(9: 1)$ at $25^{\circ} \mathrm{C}$ for $1 \mathrm{~h}$ (Scheme 4). MS analysis of the reaction mixture showed peaks centered at $m / z=391.2$ corresponding to the click product $[\mathbf{8}]^{2+}$ (calc. $m / z=391.1)$. The signal of the starting material $[2]^{2+}$ at calc. $m / z=303.6$ had disappeared. After liquid-liquid extraction from dichloromethane, the ${ }^{1} \mathrm{H}$ NMR spectrum in acetone- $\mathrm{d}_{6}$ showed no singlet peak at $4.56 \mathrm{ppm}$ corresponding to the terminal alkyne, but a new singlet at $9.04 \mathrm{ppm}$ for triazole formation was shown (Figure S3). Overall, the CuAAC reaction on $[2]\left(\mathrm{PF}_{6}\right)_{2}$ was successful, and full conversion after a 1 -h reaction time was demonstrated.

Investigation of the Interaction between $[2]^{2+}$ and BSA. The interaction of $[2]\left(\mathrm{PF}_{6}\right)_{2}$ and $\mathrm{BSA}$ was investigated by fluorophore-labeling via the CuAAC reaction on the alkynefunctionalized complex-BSA adduct with an azide-fluorophore (Alexa Fluor 647 azide, Alexa647, Figure S8) and analyzed by gel electrophoresis (Figure 4). Incubation of Hmte-protected [2] $\left(\mathrm{PF}_{6}\right)_{2}(75 \mu \mathrm{M})$ with BSA $(15 \mu \mathrm{M})$ for $24 \mathrm{~h}$ at $37^{\circ} \mathrm{C}$ in the dark did not result in a fluorescent signal after the CuAAC reaction (Figure 4, lane 1), indicating that the protected complex could not bind to BSA. However, when the mixture was irradiated with green light $\left(\lambda_{\mathrm{ex}}=520 \mathrm{~nm}\right)$ for $1 \mathrm{~h}$ and then further incubated with BSA in the dark for 6 or $24 \mathrm{~h}$, a fluorescent band appeared between 55 and $70 \mathrm{kDa}$ (Figure 4, lane 6 for $6 \mathrm{~h}$ and lane 12 for $24 \mathrm{~h}$ ). This result indicated that (i) light activation of the complex was successful and allowed for controlling the interaction of the complex with BSA, (ii) the complex-BSA adduct can be labeled with a fluorophore by $\mathrm{CuAAC}$, and (iii) adduct formation between the ruthenium complex and BSA increases over time (quantitatively shown by elevated levels of fluorescence intensity of the band when going from a 6- to 24-h incubation time). Several negative controls were performed, e.g., samples with nonfunctionalized complex $[1]\left(\mathrm{PF}_{6}\right)_{2}$ (Figure 4, lanes 3 and 8 ) or without any complex (Figure 4, lane 5). These samples did not result in any significant labeling. A low background fluorescence in lanes 1 , $3,5,8,9,11$ was observed due to unspecific binding of the fluorophore Alexa647 to BSA. Indeed, this was confirmed by BSA-free controls (Figure 4, lane 4) and fluorophore-free controls (lanes 2, 7, and 10 in Figure 4), as these did not exhibit any fluorescence. If not activated, $[2]\left(\mathrm{PF}_{6}\right)_{2}$ remained thermally stable for the entire incubation time (Figure 4, lane 13, and Figure S5). Upon increased BSA concentrations, the intensity of the fluorescent band increased as well (BSA concentrations vary from 5 to $20 \mu \mathrm{M}, \mathrm{Ru}$ :BSA 5:1, 5:3, and 5:5, Figures $S 9$ and S10). These experiments showed that the fluorescence intensity of the bands is correlated to the increased BSA concentration. Thus, the interaction between $[2]^{2+}$ and BSA appears to be concentration-dependent.

To further explore the added value of this gel-based method for studying the BSA-Ru interaction, compared to existing ones, the interaction between the ruthenium complex $[1]^{2+}$ or $[2]^{2+}$ and BSA was also investigated with $\mathrm{UV}-$ vis spectroscopy. First, the absorbance spectra of solutions of only the complexes $(15 \mu \mathrm{M})$ or BSA $(15 \mu \mathrm{M})$ were recorded separately in PBS in the dark for $24 \mathrm{~h}$ at $37{ }^{\circ} \mathrm{C}$ (Figures S11 and S12). The unchanged UV-vis spectra indicated the thermal stability of both individual species. Thereafter, the absorbance spectra of mixtures of the ruthenium complexes $(15 \mu \mathrm{M})$ and BSA (15 $\mu \mathrm{M})$ were recorded under the same conditions. The spectrum of the solution of $[1]\left(\mathrm{PF}_{6}\right)_{2}$ and BSA did not change during 24 $\mathrm{h}$, as expected for the Hmte-protected complex (Figure 5a).

Table 2. Maximum Absorption Wavelengths $\left(\lambda_{\max }\right.$ in $\left.\mathrm{nm}\right)$, Molar Absorption Coefficient $\left(\varepsilon\right.$ in $\left.\mathbf{M}^{-1} \cdot \mathrm{cm}^{-1}\right)$, Phosphorescence Quantum Yield $\left(\Phi_{\mathrm{P}}\right)$ in Methanol-d $\mathrm{d}_{6}$, Singlet Oxygen Generation Quantum Yield $\left(\Phi_{\Delta}\right)$ in Methanol-d $\mathrm{d}_{6}$, and Photosubstitution Quantum Yields in Water $\left(\Phi_{\max }\right.$ at $\left.25^{\circ} \mathrm{C}\right)$ for Complexes $[2]\left(\mathrm{PF}_{6}\right)_{2}$ and $[1]\left(\mathrm{PF}_{6}\right)_{2}$

$\begin{array}{cccccc} & \lambda_{\max }{ }^{a} & \varepsilon_{\lambda_{\max }{ }^{a}} & \Phi_{\mathrm{P}}{ }^{b} & \Phi_{\Delta}{ }^{b} & \Phi_{\max }^{a} \\ {[\mathbf{2}]\left(\mathrm{PF}_{6}\right)_{2}} & 470 & 9.54 \times 10^{3} & <1.0 \times 10^{-4} & 0.007 & 0.017^{d} \\ {[1]\left(\mathrm{PF}_{6}\right)_{2}} & 450^{c} & 6.60 \times 10^{3 c} & <1.0 \times 10^{-4} & <0.005 & 0.022^{c, e}\end{array}$

${ }^{a}$ In Milli-Q water. ${ }^{b}$ In methanol-d $6 \cdot{ }^{c}$ Data from Bahreman et al. ${ }^{62}{ }^{d}$ At $466 \mathrm{~nm}, \mathrm{~T}=37{ }^{\circ} \mathrm{C} .{ }^{e}$ At $452 \mathrm{~nm}, \mathrm{~T}=24{ }^{\circ} \mathrm{C}$. 
Scheme 4. Reaction Procedure of the CuAAC Reaction of $[2]\left(\mathrm{PF}_{6}\right)_{2}$ with $\mathrm{R}-\mathrm{N}_{3}$ (2-(2-(2-Azidoethoxy)ethoxy)ethanol)

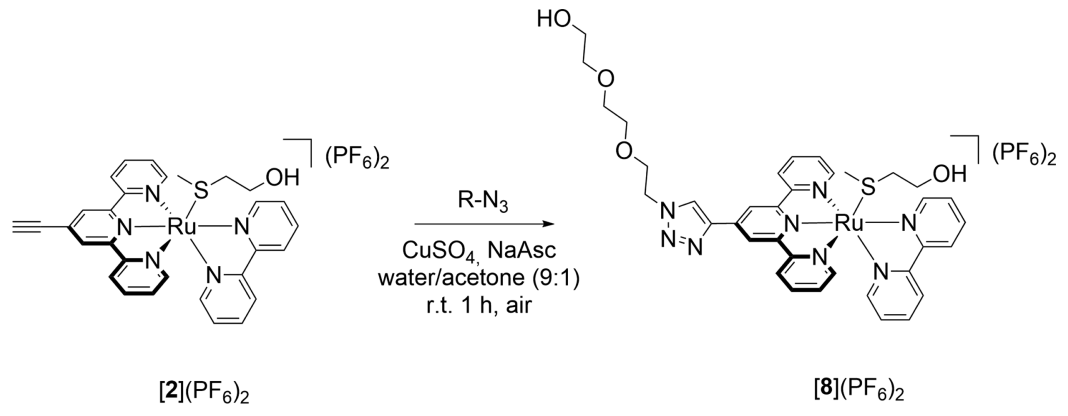

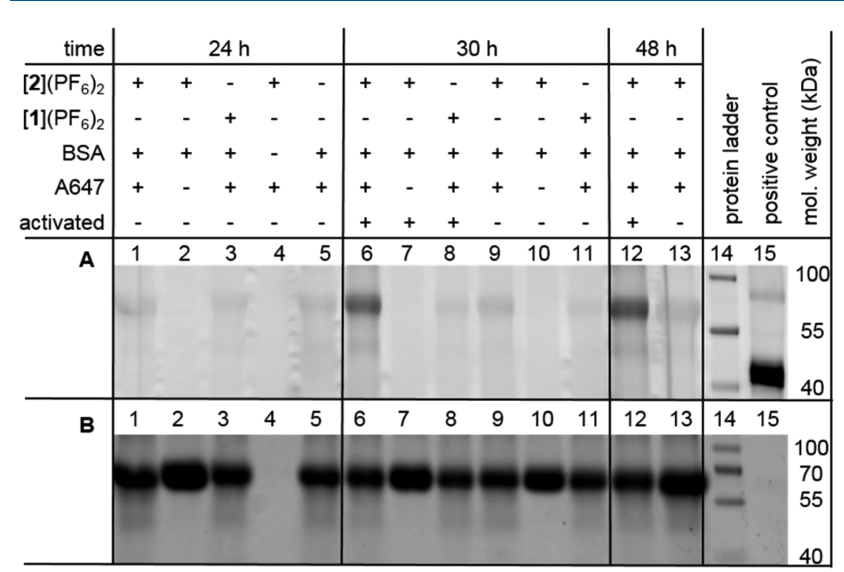

Figure 4. Polyacrylamide gel electrophoresis (PAGE) showing postlabeled Ru-bound BSA (A). Fluorescence labeling is achieved via the click reaction with Alexa647. The protecting Hmte ligand of $[2]\left(\mathrm{PF}_{6}\right)_{2}$ prevents interaction with BSA, resulting in the absence of fluorescence labeling (lanes 1, 9, and 13). Light irradiation after $24 \mathrm{~h}$ generates the aqua complex $[7]^{2+}$ that interacts with BSA after a 6 and 24-h incubation in the dark after light activation (lanes 6 and 12, respectively). Control reactions with alkyne-free $[1]\left(\mathrm{PF}_{6}\right)_{2}$ (lanes 3, 8, and 11), without Alexa647 (lanes 2, 7, and 10), and without BSA (lane 4) show no fluorescent labeling. Coomassie staining (B). Conditions: $[\mathrm{Ru}]=75 \mu \mathrm{M},[\mathrm{BSA}]=15 \mu \mathrm{M}$. Green light activation: $\lambda$ $=520 \mathrm{~nm}$, light dosage: $76 \mathrm{~J} / \mathrm{cm}^{2}, t=1 \mathrm{~h}, T=37{ }^{\circ} \mathrm{C}$. Click conditions: $2.5 \mu \mathrm{M}$ Alexa647, $3.2 \mathrm{mM} \mathrm{CuSO}_{4}, 18.8 \mathrm{mM} \mathrm{NaAsc}, 0.7$ $\mathrm{mM}$ THPTA, $46.3 \mathrm{mM}$ Tris-HCl, $t=1 \mathrm{~h}, T=25^{\circ} \mathrm{C}$. Lane 14: prestained protein ladder, lane 15: positive control: alkyne-substituted vinculin, homopropargylglycine-Vin.

However, when using the aqua complex $[6]^{2+}$, the UV-vis spectrum also did not show any change (Figure $5 \mathrm{~b}$ ). Similar results were obtained when using alkyne-functionalized complexes $[2]^{2+}$ and $[7]^{2+}$ in the presence of BSA (Figure $5 c, d)$. Therefore, it appeared that the interaction between ruthenium complexes and BSA after light activation cannot be monitored using UV-vis spectroscopy under the conditions reported.

Mass spectrometry (MS) is also a very powerful method to study protein-metallodrug interactions, in particular when the coordination bonds between the protein residues and the metal center resist sample preparation and the conditions inside the MS apparatus. ${ }^{63,73,74}$ ESI-MS was hence investigated as a second traditional method to visualize the binding of BSA to the light-activated ruthenium complex. Different mixtures of $[1]\left(\mathrm{PF}_{6}\right)_{2}(100,300$, or $500 \mu \mathrm{M})$ and BSA $(100 \mu \mathrm{M})$ in aqueous solution were incubated at $37^{\circ} \mathrm{C}$ for $24 \mathrm{~h}$ in the dark and were activated thereafter with green light $(515 \mathrm{~nm})$ for 1 $h$. Twenty-four $h$ after light activation, samples were subjected to ESI-MS analysis. The presence of the activated ruthenium species led to a signal broadening and loss of spectral resolution compared to BSA only $(66,429 \mathrm{Da})$. However, no evident signals that can be ascribed to Ru-BSA adducts were detected. To improve the signal, ultrafiltration with a $10 \mathrm{kDa}$ cutoff was performed, followed by extensive washing steps. Upon this treatment, spectra showed a better resolution, but the signal showed only unreacted BSA. Analysis of the ultrafiltered fraction by ICP-AES revealed that indeed very little ruthenium was present in the BSA samples (Table S1). These results suggest that the interaction between the ruthenium species and BSA is too weak to be detected by ESI mass spectrometry. Control experiments with $[2]\left(\mathrm{PF}_{6}\right)_{2}$ were performed and resulted in similar spectra, indicating that alkyne functionalization did not cause an enhanced interaction of the ruthenium center with BSA.

Finally, next to UV-vis spectroscopy and mass spectrometry, tryptophan fluorescence spectroscopy is a common technique to investigate the interaction of metal complexes with serum albumin. BSA has two tryptophan residues: one buried at position 214 , and another one at the surface of the protein at position $131 .^{75}$ The intrinsic fluorescence of tryptophan is highly sensitive to the environment, and small conformational changes, e.g., caused by the interaction of small molecules with the protein, can lead to the quenching of the fluorescence. However, complexes $[1]\left(\mathrm{PF}_{6}\right)_{2},[2]\left(\mathrm{PF}_{6}\right)_{2}$, and their corresponding aqua complexes absorb at the excitation and emission wavelength of BSA (280 and $350 \mathrm{~nm}$, respectively). Therefore, a visible decrease of the fluorescence might be due (i) not only to the quenching of the fluorescence due to complex interactions with the protein but (ii) also to the absorption of the exciting light by the metal complexes (filter effect) or (iii) the reabsorption of the fluorescence emission of the protein by the added complex. Hence, fluorescence spectroscopy could not be used to study the interaction between $[\mathbf{1}]^{2+}$ or $[\mathbf{2}]^{2+}$ and BSA.

The chemical biology method developed in this work, which is based on fluorescent labeling of the metallodrug by click chemistry after binding to the protein of interest (here BSA), clearly showed that the light-activated ruthenium complex interacts with BSA and that this interaction is concentrationand light-dependent. Thus, the basic idea of metal-based PACT, that interaction of the ruthenium center with biomolecules is prevented by coordination of a well-bound thioether ligand and recovered upon light irradiation, is validated here for the first time with a protein (BSA). On the other hand, as no signal of a ruthenated protein was observed by ESI mass spectrometry, coordination of the BSA protein to the unprotected ruthenium(II) aqua complex appears to be too weak to be studied by this technique. Direct 
a)

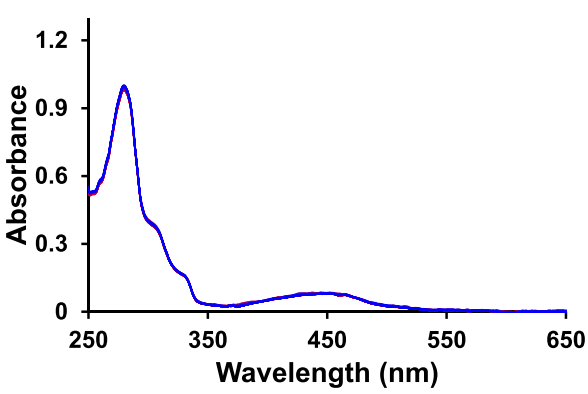

c)

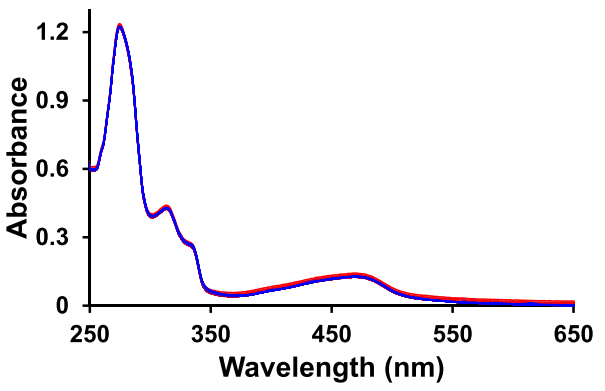

b)

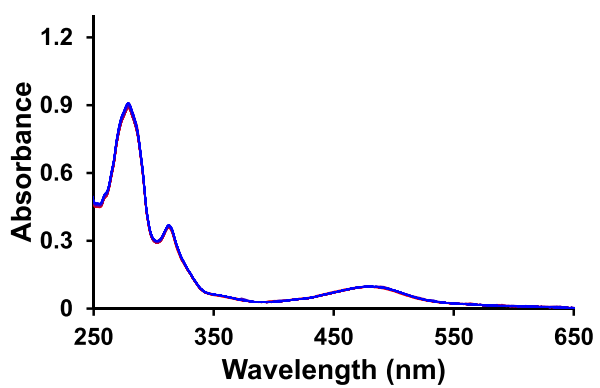

d)

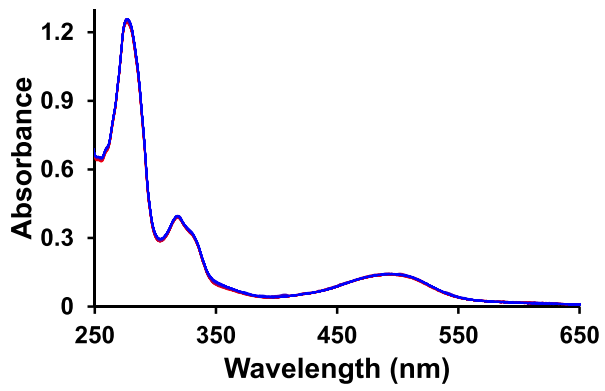

Figure 5. Evolution of the UV-vis spectra (region 250-650 nm) of a solution of a ruthenium complex (0.015 mM) with BSA (0.015 mM) in PBS under air atmosphere for $24 \mathrm{~h}$ at $\left.\left.\left.37^{\circ} \mathrm{C}: \mathrm{a}\right)[\mathbf{1}]\left(\mathrm{PF}_{6}\right)_{2}, \mathrm{~b}\right)[6]^{2+}, \mathrm{c}\right)[2]\left(\mathrm{PF}_{6}\right)_{2}$, and d) $[7]^{2+}$.

Table 3. Overview of Ru-BSA Interaction Studies

\begin{tabular}{|c|c|c|c|}
\hline technique & concentrations $^{a}$ & result & conclusion \\
\hline $\mathrm{PAGE}+\mathrm{CuAAC}$ & $\begin{array}{l}{[\mathrm{Ru}]=75 \mu \mathrm{M}} \\
{[\mathrm{BSA}]=15 \mu \mathrm{M}}\end{array}$ & $\begin{array}{l}\text { fluorescent band after light activation }+\mathrm{CuAAC} \\
\text { no fluorescent band in the dark or without click handle }\end{array}$ & $\begin{array}{l}\text { Ru-BSA interaction controlled by light; it withstands } \\
\text { CuAAC conditions }\end{array}$ \\
\hline UV-vis & $\begin{array}{l}{[\mathrm{Ru}]=15 \mu \mathrm{M}} \\
{[\mathrm{BSA}]=15 \mu \mathrm{M}}\end{array}$ & $\begin{array}{l}\text { no change in UV-vis spectrum for activated ruthenium } \\
\text { compound in the presence of BSA }\end{array}$ & $\mathrm{Ru}-\mathrm{BSA}$ interaction cannot be visualized by UV-vis \\
\hline ESI-MS & $\begin{array}{l}{[\mathrm{Ru}]=500 \mu \mathrm{M}} \\
{[\mathrm{BSA}]=100 \mu \mathrm{M}}\end{array}$ & no signal of ruthenated BSA & $\begin{array}{l}\text { Ru-BSA interaction too weak for mass spectrometry } \\
\text { analysis }\end{array}$ \\
\hline
\end{tabular}

${ }^{a} \mathrm{Ru}$ represents either $[\mathbf{1}]\left(\mathrm{PF}_{6}\right)_{2}$ or $[2]\left(\mathrm{PF}_{6}\right)_{2}$. Conditions: After a 24 -h incubation in the dark $\left(37^{\circ} \mathrm{C}\right)$, the samples were activated by $1 \mathrm{~h}$ of green light irradiation at $37^{\circ} \mathrm{C}$ and further incubated for at least $24 \mathrm{~h}$.

coordination of methionine or histidine residues to the ruthenium complex, as seen with other ruthenium complexes, ${ }^{23,76-80}$ can also be excluded by the absence of changes in the UV-vis spectrum of a mixture of the complex and the protein. In addition to methionine and histidine, BSA contains 35 cysteine residues, forming 17 disulfide bridges. Therefore, only one thiol group is available for metal binding, Cys34. ${ }^{81}$ However, the bond between cysteine and ruthenium(II) is oxygen-sensitive. As demonstrated by our group, ${ }^{82}$ once coordinated to $\left[\mathrm{Ru}(\mathrm{tpy})(\mathrm{bpy})\left(\mathrm{OH}_{2}\right)\right]^{2+}$, cysteine is readily oxidized in air, which leads to the formation of unstable sulfenato and sulfinato ruthenium complexes that further release the hydrolyzed ruthenium complexes $[6]^{2+}$ and $[7]^{2+}$ and the sulfinated or sulfenated BSA protein. Since in-gel fluorescence showed that the intensity of the fluorescent band corresponding to the ruthenated BSA increased with incubation time, stable coordination of Cys34 to the metal can be excluded due to the instability over time of $[\mathrm{Ru}(\mathrm{tpy})(\mathrm{bpy})(\mathrm{Cys})]^{2+}$ complexes. The last remaining hypothesis that may explain the interaction seen in Figure 4 after light activation is a combination of, on the one hand, the noncovalent interaction between the light-activated ruthenium complex and the hydrophobic core of BSA, similar to what has been described for KP1019 with HSA, ${ }^{83,84}$ and, on the other hand, weak coordination to heteroatom-containing side chains of the protein, as this interaction does not take place in the dark. Overall, it is important to realize that (i) the interaction between the photoactivated aqua complexes $[7]^{2+}$ and BSA is weak and (ii) the concentrations necessary for studying this interaction by the three different techniques used in this work differ each by almost 1 order of magnitude (Table 3 ). It is unclear what the concentrations of ruthenium might be in biologically relevant conditions and which role such differences in concentration would play on the thermodynamics and kinetics of ruthenium binding to BSA. This being said, it appears that probing the weak interaction between ruthenium and BSA is possible using the CuAAC-based gel electrophoresis method presented here but not using UV-vis or ESIMS (Table 3).

\section{CONCLUSION}

A synthetic route was developed for the functionalization of a photolabile ruthenium complex $[\mathbf{1}]^{2+}$ with a free alkyne handle. The TBDMS group appears to be the best protecting group during ligand introduction and exchange, as it prevents the formation of side products when a free coordination site appears on ruthenium near the alkyne group. In addition, the TBDMS protecting group is easily removed with a small excess of potassium fluoride, without the need of introducing bioactive silver ions. The small alkyne handle allowed for fluorophore postlabeling via CuAAC, which allowed for studying the interaction between the ruthenium complex 
$[7]^{2+}$ and BSA. Importantly, this interaction could not be detected with traditional methods such as UV-vis spectroscopy, fluorescence spectroscopy, or ESI mass spectrometry. In addition, fluorophore postlabeling on a gel also demonstrated that the thioether ligand effectively protected the ruthenium complex $[\mathbf{1}]^{2+}$ or $[\mathbf{2}]^{2+}$ from interacting with the BSA protein, a concept that lies at the core of photoactivated chemotherapy. ${ }^{60}$ Overall, fluorophore labeling via CuAAC on a gel appears to be an excellent way to visualize weak interactions between light-activated, nonemissive ruthenium compounds and proteins such as BSA.

\section{ASSOCIATED CONTENT}

\section{(s) Supporting Information}

The Supporting Information is available free of charge at https://pubs.acs.org/doi/10.1021/acs.inorgchem.0c00742.

NMR spectra, details for CuAAC reaction on $[2]\left(\mathrm{PF}_{6}\right)_{2}$, enol ether formation catalyzed by ruthenium, dark stability data, spectroscopic details for photosubstitution, singlet oxygen generation, fluorophore labeling details, and UV-vis spectra controls for Ru:BSA interaction (PDF)

\section{Accession Codes}

CCDC 1968301 contains the supplementary crystallographic data for this paper. These data can be obtained free of charge via www.ccdc.cam.ac.uk/data_request/cif, or by emailing data_request@ccdc.cam.ac.uk, or by contacting The Cambridge Crystallographic Data Centre, 12 Union Road, Cambridge CB2 1EZ, UK; fax: +44 1223336033.

\section{AUTHOR INFORMATION}

\section{Corresponding Author}

Sylvestre Bonnet - Leiden Institute of Chemistry, Leiden University, 2333CC Leiden, The Netherlands; (1) orcid.org/ 0000-0002-5810-3657; Email: bonnet@chem.leidenuniv/nl

\section{Authors}

Anja Busemann - Leiden Institute of Chemistry, Leiden University, 2333CC Leiden, The Netherlands

Can Araman - Leiden Institute of Chemistry, Leiden University, 2333CC Leiden, The Netherlands; 이이이.org/0000-00026961-5607

Ingrid Flaspohler - Leiden Institute of Chemistry, Leiden University, 2333CC Leiden, The Netherlands

Alessandro Pratesi - Department of Chemistry and Industrial Chemistry, University of Pisa, 56124 Pisa, Italy; 이이. org/ 0000-0002-9553-9943

Xue-Quan Zhou - Leiden Institute of Chemistry, Leiden University, 2333CC Leiden, The Netherlands

Vincent H. S. van Rixel - Leiden Institute of Chemistry, Leiden University, 2333CC Leiden, The Netherlands

Maxime A. Siegler - Small Molecule X-ray Facility, Department of Chemistry, John Hopkins University, Baltimore, Maryland 21218, United States; orcid.org/0000-0003-4165-7810

Luigi Messori - Laboratory of Metals in Medicine (MetMed), Department of Chemistry 'Ugo Schiff', University of Florence, 50019 Florence, Italy; 10 orcid.org/0000-0002-9490-8014

Sander I. van Kasteren - Leiden Institute of Chemistry, Leiden University, 2333CC Leiden, The Netherlands; (o orcid.org/ 0000-0003-3733-818X

Complete contact information is available at: https://pubs.acs.org/10.1021/acs.inorgchem.0c00742

\section{Notes}

The authors declare no competing financial interest.

\section{ACKNOWLEDGMENTS}

The European Research Council is kindly acknowledged for financial support to S.B. and S.I.V.K. via a Starting Grant. NWO is kindly acknowledged for financial support to S.B. via a VIDI grant and an ECHO grant to S.I.V.K. Prof. Elisabeth Bouwman is kindly acknowledged for her continuous support. L.M. and A.P. acknowledge the Fondazione Italiana per la Ricerca sul Cancro (AIRC), Milan, and Fondazione Cassa Risparmio Firenze for funding the project "Advanced mass spectrometry tools for cancer research: novel applications in proteomics, metabolomics and nanomedicine" (Multiuser Equipment Program 2016, ref. code 19650). A.P. thanks the University of Pisa (Rating Ateneo 2019) for the financial support.

\section{REFERENCES}

(1) Groessl, M.; Zava, O.; Dyson, P. J. Cellular uptake and subcellular distribution of ruthenium-based metallodrugs under clinical investigation versus cisplatin. Metallomics 2011, 3, 591-599.

(2) Frei, A.; Rubbiani, R.; Tubafard, S.; Blacque, O.; Anstaett, P.; Felgenträger, A.; Maisch, T.; Spiccia, L.; Gasser, G. Synthesis, Characterization, and Biological Evaluation of $\mathrm{New} \mathrm{Ru}(\mathrm{II})$ Polypyridyl Photosensitizers for Photodynamic Therapy. J. Med. Chem. 2014, 57, 7280-7292.

(3) Morais, T. S.; Santos, F. C.; Jorge, T. F.; Côrte-Real, L.; Madeira, P. J. A.; Marques, F.; Robalo, M. P.; Matos, A.; Santos, I.; Garcia, M. H. New water-soluble ruthenium(II) cytotoxic complex: Biological activity and cellular distribution. J. Inorg. Biochem. 2014, 130, 1-14.

(4) Côrte-Real, L.; Mendes, F.; Coimbra, J.; Morais, T. S.; Tomaz, A. I.; Valente, A.; Garcia, M. H.; Santos, I.; Bicho, M.; Marques, F. Anticancer activity of structurally related ruthenium(II) cyclopentadienyl complexes. JBIC, J. Biol. Inorg. Chem. 2014, 19, 853-867.

(5) Massai, L.; Pratesi, A.; Gailer, J.; Marzo, T.; Messori, L. The cisplatin/serum albumin system: A reappraisal. Inorg. Chim. Acta 2019, 495, 118983.

(6) Pratesi, A.; Cirri, D.; Fregona, D.; Ferraro, G.; Giorgio, A.; Merlino, A.; Messori, L. Structural Characterization of a Gold/Serum Albumin Complex. Inorg. Chem. 2019, 58, 10616-10619.

(7) Pratesi, A.; Cirri, D.; Ciofi, L.; Messori, L. Reactions of Auranofin and Its Pseudohalide Derivatives with Serum Albumin Investigated through ESI-Q-TOF MS. Inorg. Chem. 2018, 57, 1050710510.

(8) Walker, H. K.; Hall, W. D.; Hurst, J. W. Clinical Methods: The History, Physical, and Laboratory Examinations, 3rd ed.; Butterworths: Boston, 1990.

(9) Sullivan, M. P.; Holtkamp, H. U.; Hartinger, C. G. In MetalloDrugs: Development and Action of Anticancer Agents; Sigel, A., Sigel, H., Freisinger, E., Sigel, R. K. O., Eds.; Walter de Gruyter GmbH: Berlin/ Boston, 2018; Chapter 13, Vol. 18, pp 351-386, DOI: 10.1515/ 9783110470734.

(10) Zhang, Y.; Ho, A.; Yue, J.; Kong, L.; Zhou, Z.; Wu, X.; Yang, F.; Liang, H. Structural basis and anticancer properties of rutheniumbased drug complexed with human serum albumin. Eur. J. Med. Chem. 2014, 86, 449-455.

(11) Mayr, J.; Heffeter, P.; Groza, D.; Galvez, L.; Koellensperger, G.; Roller, A.; Alte, B.; Haider, M.; Berger, W.; Kowol, C. R.; Keppler, B. $\mathrm{K}$. An albumin-based tumor-targeted oxaliplatin prodrug with distinctly improved anticancer activity in vivo. Chem. Sci. 2017, 8, 2241-2250.

(12) Bergamo, A.; Masi, A.; Peacock, A. F. A.; Habtemariam, A.; Sadler, P. J.; Sava, G. In vivo tumour and metastasis reduction and in vitro effects on invasion assays of the ruthenium RM175 and osmium AFAP51 organometallics in the mammary cancer model. J. Inorg. Biochem. 2010, 104, 79-86. 
(13) Timerbaev, A. R.; Hartinger, C. G.; Aleksenko, S. S.; Keppler, B. K. Interactions of antitumor metallodrugs with serum proteins: advances in characterization using modern analytical methodology. Chem. Rev. 2006, 106, 2224-2248.

(14) Ferraro, G.; Massai, L.; Messori, L.; Merlino, A. Cisplatin binding to human serum albumin: a structural study. Chem. Commun. 2015, 51, 9436-9439.

(15) Wragg, A.; Gill, M. R.; McKenzie, L.; Glover, C.; Mowll, R.; Weinstein, J. A.; Su, X.; Smythe, C.; Thomas, J. A. Serum Albumin Binding Inhibits Nuclear Uptake of Luminescent Metal-ComplexBased DNA Imaging Probes. Chem. - Eur. J. 2015, 21, 11865-11871.

(16) Huang, B. X.; Kim, H.-Y.; Dass, C. Probing three-dimensional structure of bovine serum albumin by chemical cross-linking and mass spectrometry. J. Am. Soc. Mass Spectrom. 2004, 15, 1237-1247.

(17) Bijelic, A.; Theiner, S.; Keppler, B. K.; Rompel, A. X-ray Structure Analysis of Indazolium trans-[Tetrachlorobis(1H-indazole)ruthenate(III)] (KP1019) Bound to Human Serum Albumin Reveals Two Ruthenium Binding Sites and Provides Insights into the Drug Binding Mechanism. J. Med. Chem. 2016, 59, 5894-5903.

(18) Merlino, A. Interactions between proteins and $\mathrm{Ru}$ compounds of medicinal interest: A structural perspective. Coord. Chem. Rev. 2016, 326, 111-134.

(19) Casini, A.; Karotki, A.; Gabbiani, C.; Rugi, F.; Vasak, M.; Messori, L.; Dyson, P. J. Reactivity of an antimetastatic organometallicruthenium compound with metallothionein-2: relevance to the mechanism of action. Metallomics 2009, 1, 434-441.

(20) Casini, A.; Gabbiani, C.; Mastrobuoni, G.; Pellicani, R. Z.; Intini, F. P.; Arnesano, F.; Natile, G.; Moneti, G.; Francese, S.; Messori, L. Insights into the Molecular Mechanisms of Protein Platination from a Case Study: The Reaction of Anticancer Platinum(II) Iminoethers with Horse Heart Cytochrome c. Biochemistry 2007, 46, 12220-12230.

(21) Nišavić, M.; Stoiljković, M.; Crnolatac, I.; Milošević, M.; Rilak, A.; Masnikosa, R. Highly water-soluble ruthenium(II) terpyridine coordination compounds form stable adducts with blood-borne metal transporting proteins. Arabian J. Chem. 2018, 11, 291-304.

(22) Galvez, L.; Theiner, S.; Grabarics, M.; Kowol, C. R.; Keppler, B. K.; Hann, S.; Koellensperger, G. Critical assessment of different methods for quantitative measurement of metallodrug-protein associations. Anal. Bioanal. Chem. 2018, 410, 7211-7220.

(23) Piccioli, F.; Sabatini, S.; Messori, L.; Orioli, P.; Hartinger, C. G.; Keppler, B. K. A comparative study of adduct formation between the anticancer ruthenium(III) compound HInd trans-[RuCl4(Ind)2] and serum proteins. J. Inorg. Biochem. 2004, 98, 1135-1142.

(24) Trynda-Lemiesz, L.; Karaczyn, A.; Keppler, B. K.; Kozlowski, $\mathrm{H}$. Studies on the interactions between human serum albumin and trans-indazolium (bisindazole) tetrachlororuthenate(III). J. Inorg. Biochem. 2000, 78, 341-346.

(25) Santos, R. L. S. R.; Sanches, R. N. F.; de Oliveira Silva, D. Spectroscopic studies on interactions of the tetrakis(acetato)chloridodiruthenium(II, III) complex and the Ru2(II, III)-NSAIDderived metallodrugs of ibuprofen and ketoprofen with human serum albumin. J. Coord. Chem. 2015, 68, 3209-3228.

(26) Ricciardi, L.; Pucci, D.; Pirillo, S.; La Deda, M. Emission solvatochromic behavior of a pentacoordinated $\mathrm{Zn}$ (II) complex_ A viable tool for studying the metallodrug-protein interaction. J. Lumin. 2014, 151, 138-142.

(27) Demoro, B.; de Almeida, R. F. M.; Marques, F.; Matos, C. P.; Otero, L.; Costa Pessoa, J.; Santos, I.; Rodríguez, A.; Moreno, V.; Lorenzo, J.; Gambino, D.; Tomaz, A. I. Screening organometallic binuclear thiosemicarbazone ruthenium complexes as potential antitumour agents: cytotoxic activity and human serum albumin binding mechanism. Dalton Trans. 2013, 42, 7131-16.

(28) Demoro, B.; Bento-Oliveira, A.; Marques, F.; Costa Pessoa, J.; Otero, L.; Gambino, D. F. M.; de Almeida, R.; Tomaz, A. I. Interaction with Blood Proteins of a Ruthenium(II) Nitrofuryl Semicarbazone Complex: Effect on the Antitumoral Activity. Molecules 2019, 24, 2861-19.
(29) Nišavić, M.; Janjić, G. V.; Hozić, A.; Petković, M.; Milšić, M. K.; Vujšíc, Z.; Cindrić, M. Positive and negative nano-electrospray mass spectrometry of ruthenated serum albumin supported by docking studies: an integrated approach towards defining metallodrug binding sites on proteins. Metallomics 2018, 10, 587-594.

(30) Matczuk, M.; Kupiec, M.; Legat, J.; Pawlak, K.; Timerbaev, A. R.; Jarosz, M. Use of high-performance liquid chromatographytandem electrospray ionization mass spectrometry to assess the speciation of a ruthenium(III) anticancer drug in the cytosol of cancer cells. Anal. Bioanal. Chem. 2015, 407, 4857-4862.

(31) Ho, M.-Y.; Chiou, M.-L.; Du, W.-S.; Chang, F. Y.; Chen, Y.-H.; Weng, Y.-J.; Cheng, C.-C. Inductive properties of polypyridyl ruthenium complexes significantly regulate various protein distributions in Escherichia coli. J. Inorg. Biochem. 2011, 105, 902-910.

(32) Ho, M.-Y.; Chiou, M.-L.; Chang, R.-C.; Chen, Y.-H.; Cheng, C.-C. Outer membrane protein $\mathrm{OmpF}$ involved in the transportation of polypyridyl ruthenium complexes into Escherichia coli. J. Inorg. Biochem. 2010, 104, 614-617.

(33) Holtkamp, H.; Grabmann, G.; Hartinger, C. G. Electrophoretic separation techniques and their hyphenation to mass spectrometry in biological inorganic chemistry. Electrophoresis 2016, 37, 959-972.

(34) Polec-Pawlak, K.; Abramski, J. K.; Semenova, O.; Hartinger, C. G.; Timerbaev, A. R.; Keppler, B. K.; Jarosz, M. Platinum group metallodrug-protein binding studies by capillary electrophoresis inductively coupled plasma-mass spectrometry: A further insight into the reactivity of a novel antitumor ruthenium(III) complex toward human serum proteins. Electrophoresis 2006, 27, 1128-1135.

(35) Połeć-Pawlak, K.; Abramski, J. K.; Ferenc, J.; Foteeva, L. S.; Timerbaev, A. R.; Keppler, B. K.; Jarosz, M. Application of capillary electrophoresis-inductively coupled plasma mass spectrometry to comparative studying of the reactivity of antitumor ruthenium(III) complexes differing in the nature of counter-ion toward human serum proteins. J. Chromatogr., A 2008, 1192, 323-326.

(36) Weljie, A. M.; Yamniuk, A. P.; Yoshino, H.; Izumi, Y.; Vogel, H. J. Protein conformational changes studied by diffusion NMR spectroscopy: application to helix-loop-helix calcium binding proteins. Protein Sci. 2003, 12, 228-236.

(37) Vinje, J.; Sletten, E. NMR spectroscopy of anticancer platinum drugs. Anti-Cancer Agents Med. Chem. 2007, 7, 35-54.

(38) Li, H.; Sun, H. In-cell NMR: an emerging approach for monitoring metal-related events in living cells. Metallomics 2014, 6, 69-76.

(39) White, J. D.; Osborn, M. F.; Moghaddam, A. D.; Guzman, L. E.; Haley, M. M.; DeRose, V. J. Picazoplatin, an Azide-Containing Platinum(II) Derivative for Target Analysis by Click Chemistry. J. Am. Chem. Soc. 2013, 135, 11680-11683.

(40) Ding, S.; Qiao, X.; Suryadi, J.; Marrs, G. S.; Kucera, G. L.; Bierbach, U. Using Fluorescent Post-Labeling To Probe the Subcellular Localization of DNA-Targeted Platinum Anticancer Agents. Angew. Chem. 2013, 125, 3434-3438.

(41) Sletten, E. M.; Bertozzi, C. R. From Mechanism to Mouse: A Tale of Two Bioorthogonal Reactions. Acc. Chem. Res. 2011, 44, 666676.

(42) Jiang, X.; Hao, X.; Jing, L.; Wu, G.; Kang, D.; Liu, X.; Zhan, P. Recent applications of click chemistry in drug discovery. Expert Opin. Drug Discovery 2019, 14, 779-789.

(43) Kolb, H. C.; Sharpless, K. B. The growing impact of click chemistry on drug discovery. Drug Discovery Today 2003, 8, 11281137.

(44) Kolb, H. C.; Finn, M. G.; Sharpless, K. B. Click Chemistry: Diverse Chemical Function from a Few Good Reactions. Angew. Chem., Int. Ed. 2001, 40, 2004-2021.

(45) Rostovtsev, V. V.; Green, L. G.; Fokin, V. V.; Sharpless, K. B. A Stepwise Huisgen Cycloaddition Process: Copper(I)-Catalyzed Regioselective "Ligation" of Azides and Terminal Alkynes. Angew. Chem., Int. Ed. 2002, 41, 2596-2599.

(46) Best, M. D. Click Chemistry and Bioorthogonal Reactions: Unprecedented Selectivity in the Labeling of Biological Molecules. Biochemistry 2009, 48, 6571-6584. 
(47) Lang, K.; Chin, J. W. Bioorthogonal Reactions for Labeling Proteins. ACS Chem. Biol. 2014, 9, 16-20.

(48) Meldal, M.; Tornøe, C. W. Cu-Catalyzed Azide-Alkyne Cycloaddition. Chem. Rev. 2008, 108, 2952-3015.

(49) Baron, A.; Herrero, C.; Quaranta, A.; Charlot, M.-F.; Leibl, W.; Vauzeilles, B.; Aukauloo, A. Click Chemistry on a Ruthenium Polypyridine Complex. An Efficient and Versatile Synthetic Route for the Synthesis of Photoactive Modular Assemblies. Inorg. Chem. 2012, 51, 5985-5987.

(50) Chitre, K. P.; Guillén, E.; Yoon, A. S.; Galoppini, E. Synthesis of Homoleptic Ruthenium "Star" Complexes by Click Reaction for $\mathrm{TiO} 2$ Sensitization. Eur. J. Inorg. Chem. 2012, 2012, 5461-5464.

(51) Ott, I.; Schmidt, K.; Kircher, B.; Schumacher, P.; Wiglenda, T.; Gust, R. Antitumor-Active Cobalt-Alkyne Complexes Derived from Acetylsalicylic Acid: Studies on the Mode of Drug Action. J. Med. Chem. 2005, 48, 622-629.

(52) Zabarska, N.; Sorsche, D.; Heinemann, F. W.; Glump, S.; Rau, S. Towards Ruthenium-Based Building Blocks for CuAAC Click Reactions: Challenges in Generating Ruthenium(II) Polypyridine Alkynes. Eur. J. Inorg. Chem. 2015, 2015, 4869-4877.

(53) Gerken, J. B.; Rigsby, M. L.; Ruther, R. E.; Pérez-Rodríguez, R. J.; Guzei, I. A.; Hamers, R. J.; Stahl, S. S. Modular Synthesis of Alkyne-Substituted Ruthenium Polypyridyl Complexes Suitable for "Click" Coupling. Inorg. Chem. 2013, 52, 2796-2798.

(54) Ratte, H. T. Bioaccumulation and toxicity of silver compounds: A review. Environ. Toxicol. Chem. 1999, 18, 89-108.

(55) van Rixel, V. H. S.; Ramu, V.; Auyeung, A. B.; Beztsinna, N.; Leger, D. Y.; Lameijer, L. N.; Hilt, S. T.; Le Dévédec, S. E.; Yildiz, T.; Betancourt, T.; Gildner, M. B.; Hudnall, T. W.; Sol, V.; Liagre, B.; Kornienko, A.; Bonnet, S. Photo-Uncaging of a Microtubule-Targeted Rigidin Analogue in Hypoxic Cancer Cells and in a Xenograft Mouse Model. J. Am. Chem. Soc. 2019, 141, 18444-18454.

(56) Wang, Y.-Y.; Liu, Y.-C.; Sun, H.; Guo, D.-S. Type I photodynamic therapy by organic€“"inorganic hybrid materials: From strategies to applications. Coord. Chem. Rev. 2019, 395, 46-62.

(57) Knoll, J. D.; Turro, C. Control and utilization of ruthenium and rhodium metal complex excited states for photoactivated cancer therapy. Coord. Chem. Rev. 2015, 282-283, 110-126.

(58) Jakubaszek, M.; Goud, B.; Ferrari, S.; Gasser, G. Mechanisms of action of $\mathrm{Ru}(\mathrm{ii})$ polypyridyl complexes in living cells upon light irradiation. Chem. Commun. 2018, 54, 13040-13059.

(59) Farrer, N. J.; Salassa, L.; Sadler, P. J. Photoactivated chemotherapy (PACT): the potential of excited-state d-block metals in medicine. Dalton Trans. 2009, 10690-10701.

(60) Bonnet, S. Why develop photoactivated chemotherapy? Dalton Trans. 2018, 47, 10330-10343.

(61) Howerton, B. S.; Heidary, D. K.; Glazer, E. C. Strained Ruthenium Complexes Are Potent Light-Activated Anticancer Agents. J. Am. Chem. Soc. 2012, 134, 8324-8327.

(62) Bahreman, A.; Limburg, B.; Siegler, M. A.; Bouwman, E.; Bonnet, S. Spontaneous formation in the dark, and visible lightinduced cleavage, of a $\mathrm{Ru}-\mathrm{S}$ bond in water: a thermodynamic and kinetic study. Inorg. Chem. 2013, 52, 9456-69.

(63) Michelucci, E.; Pieraccini, G.; Moneti, G.; Gabbiani, C.; Pratesi, A.; Messori, L. Mass spectrometry and metallomics: A general protocol to assess stability of metallodrug-protein adducts in bottomup MS experiments. Talanta 2017, 167, 30-38.

(64) Marzo, T.; De Pascali, S. A.; Gabbiani, C.; Fanizzi, F. P.; Messori, L.; Pratesi, A. ESI-MS studies of the reactions of novel platinum(II) complexes containing $\mathrm{O}, \mathrm{O}^{\prime}$-chelated acetylacetonate and sulfur ligands with selected model proteins. BioMetals 2017, 30, 609-614.

(65) Landini, I.; Lapucci, A.; Pratesi, A.; Massai, L.; Napoli, C.; Perrone, G.; Pinzani, P.; Messori, L.; Mini, E.; Nobili, S. Selection and characterization of a human ovarian cancer cell line resistant to auranofin. Oncotarget 2017, 8, 96062-96078.

(66) Ciambellotti, S.; Pratesi, A.; Severi, M.; Ferraro, G.; Alessio, E.; Merlino, A.; Messori, L. The NAMI A - human ferritin system: a biophysical characterization. Dalton Trans. 2018, 47, 11429-11437.
(67) Araman, C.; Pieper-Pournara, L.; van Leeuwen, T.; Kampstra, A.; Bakkum, T.; Marqvorsen, M.; Nascimento, C.; Groenewold, M.; van der Wulp, W.; Overkleeft, H.; Ossendorp, F.; Toes, R.; van Kasteren, S. Bioorthogonal antigens allow the unbiased study of antigen processing and presentation. biorxiv.org 2019, DOI: 10.1101/ 439323.

(68) Wuts, P. G. M.; Greene, T. W. In Greene's Protective Groups in Organic Synthesis, 4th ed.; John Wiley \& Sons, Inc.: Hoboken, NJ, 2007; Chapter 8, pp 927-933, DOI: 10.1002/0471220574.

(69) Ziessel, R.; Grosshenny, V.; Hissler, M.; Stroh, C. cis$\left[\mathrm{Ru}\left(2,2^{\prime}: 6^{\prime}, 2^{\prime \prime}\right.\right.$-terpyridine)(DMSO)Cl2]: Useful Precursor for the Synthesis of Heteroleptic Terpyridine Complexes under Mild Conditions. Inorg. Chem. 2004, 43, 4262-4271.

(70) Takeuchi, K. J.; Thompson, M. S.; Pipes, D. W.; Meyer, T. J. Redox and spectral properties of monooxo polypyridyl complexes of ruthenium and osmium in aqueous media. Inorg. Chem. 1984, 23, $1845-1851$.

(71) Ruppin, C.; Dixneuf, P. H. Synthesis of enol esters from terminal alkynes catalyzed by ruthenium complexes. Tetrahedron Lett. 1986, 27, 6323-6324.

(72) van Rixel, V. H. S.; Moolenaar, G. F.; Siegler, M. A.; Messori, L.; Bonnet, S. Controlling with light the interaction between transtetrapyridyl ruthenium complexes and an oligonucleotide. Dalton Trans. 2018, 47, 507-516.

(73) Casini, A.; Mastrobuoni, G.; Ang, W. H.; Gabbiani, C.; Pieraccini, G.; Moneti, G.; Dyson, P. J.; Messori, L. ESI-MS Characterisation of Protein Adducts of Anticancer Ruthenium(II)Arene PTA (RAPTA) Complexes. ChemMedChem 2007, 2, 631-635.

(74) Hartinger, C. G.; Groessl, M.; Meier, S. M.; Casini, A.; Dyson, P. J. Application of mass spectrometric techniques to delineate the modes-of-action of anticancer metallodrugs. Chem. Soc. Rev. 2013, 42, 6186-6199.

(75) Crouse, H. F.; Potoma, J.; Nejrabi, F.; Snyder, D. L.; Chohan, B. S.; Basu, S. Quenching of tryptophan fluorescence in various proteins by a series of small nickel complexes. Dalton Trans. 2012, 41, 2720-2731.

(76) Brown, J. R. In Albumin: Structure, Function and Uses; Rosenoer, V. M., Oratz, M., Rothschild, M. A., Edd.; Pergamon: 1977; pp 2752, DOI: 10.1016/B978-0-08-019603-9.50009-0.

(77) Goldbach, R. E.; Rodriguez-Garcia, I.; van Lenthe, J. H.; Siegler, M. A.; Bonnet, S. N-Acetylmethionine and Biotin as Photocleavable Protective Groups for Ruthenium Polypyridyl Complexes. Chem. - Eur. J. 2011, 17, 9924-9929.

(78) Wang, F.; Chen, H.; Parkinson, J. A.; Murdoch, P. D. S.; Sadler, P. J. Reactions of a Ruthenium(II) Arene Antitumor Complex with Cysteine and Methionine. Inorg. Chem. 2002, 41, 4509-4523.

(79) Lazić, D.; Arsenijević, A.; Puchta, R.; Bugaršić, Ž. D.; Rilak, A. DNA binding properties, histidine interaction and cytotoxicity studies of water soluble ruthenium(ii) terpyridine complexes. Dalton Trans. 2016, 45, 4633-4646.

(80) Wang, F.; Bella, J.; Parkinson, J. A.; Sadler, P. J. Competitive reactions of a ruthenium arene anticancer complex with histidine, cytochrome $\mathrm{c}$ and an oligonucleotide. JBIC, J. Biol. Inorg. Chem. 2005, $10,147-155$.

(81) Quinlan, G. J.; Martin, G. S.; Evans, T. W. Albumin: Biochemical properties and therapeutic potential. Hepatology 2005, 41, 1211-1219.

(82) van Rixel, V. H. S.; Busemann, A.; Göttle, A. J.; Bonnet, S. Preparation, stability, and photoreactivity of thiolato ruthenium polypyridyl complexes: Can cysteine derivatives protect rutheniumbased anticancer complexes? J. Inorg. Biochem. 2015, 150, 174-181.

(83) Webb, M. I.; Chard, R. A.; Al-Jobory, Y. M.; Jones, M. R.; Wong, E. W. Y.; Walsby, C. J. Pyridine Analogues of the Antimetastatic $\mathrm{Ru}(\mathrm{III})$ Complex NAMI-A Targeting Non-Covalent Interactions with Albumin. Inorg. Chem. 2012, 51, 954-966.

(84) Zheng, Y.-R.; Suntharalingam, K.; Johnstone, T. C.; Yoo, H.; Lin, W.; Brooks, J. G.; Lippard, S. J. Pt(IV) Prodrugs Designed to Bind Non-Covalently to Human Serum Albumin for Drug Delivery. J. Am. Chem. Soc. 2014, 136, 8790-8798. 